\title{
TOPSIS ve MOORA Yöntemleri ile Avrupa Birliği'ne Üye Olan Ülkelerin ve Türkiye'nin Ekonomik Göstergelere Göre Sıralanması
}

\author{
Ranking of European Union Member Countries and Turkey \\ According to the Economic Indicators with TOPSIS and MOORA Methods
}

\author{
Hakan Sevgin - Yrd. Doç. Dr. Nilsen Kundakcı
}

\begin{abstract}
Öz
Bu çalışmanin amacı, Avrupa Birliğine (AB) üye olan ülkelerin ve Türkiye’nin gelişmişlik düzeylerine göre ekonomik göstergeler kullanılarak çok kriterli karar verme (ÇKKV) yöntemlerinden TOPSIS ve MOORA ile sıralanmasıdır. Ülkeler arasındaki sıralamaya ulaşmak adina öncelikle alternatifler, AB'ye üye olan 28 ülke ve aday ülke Türkiye olarak belirlenirken, kriterler ise kişi başına gelir (GSYIH/Nüfus), enflasyon, işsizlik oranı, ihracatın ithalatı karşılama oranı (İhracat) İthalat), kamu borçları/GSYİH ve bütçe açı̆̆ı/GSYIH olarak belirlenmiştir. Bu kriterler doğrultusunda AB'ye üye 28 ülke ve Türkiye arasinda gelişmişlik düzeylerine göre siralamaya TOPSIS ve MOORA yöntemleri ile ulaşılmış ve sonuçlar karşılaştıılmıştır. Elde edilen sonuçlara göre, ilk üç sırada Lüksemburg, İsveç ve Danimarka yer alirken, son siralarda ise Hirvatistan, Bulgaristan, Slovenya, Yunanistan ve Türkiye yer almıştır.
\end{abstract}

Anahtar Kelimeler: Çok Kriterli Karar Verme (ÇKKV), TOPSIS Yöntemi, MOORA Yöntemi

\begin{abstract}
The aim of this study is to determine the ranking of the member countries of European Union (EU) and Turkey according to the level of development using economic indicators with multi-criteria decision making (MCDM) methods TOPSIS and MOORA. In order to
\end{abstract}

obtain the ranking of the countries, firstly alternatives are determined as 28 European Union countries and Turkey as a candidate country. Then criteria are determined as per capita income (GDP/Population), inflation, unemployment rate, ratio of exports to imports (exports/imports), public expenditures/GDP and budget deficit/GDP. By using these criteria, the ranking of $28 \mathrm{EU}$ member countries and Turkey according to the to the level of development are determined with TOPSIS and MOORA methods and the results are compared. According to the obtained results, the first three countries are Luxembourg, Sweden and Denmark while Croatia, Bulgaria, Slovenia Greece and Turkey has taken place at the bottom of the list.

Keywords: Multi Criteria Decision Making (MCDM), TOPSIS Method, MOORA Method

\section{Giriş}

Avrupa Birliği (AB)'nin temelini, II. Dünya Savaşı sonrasında dönemin en önemli sanayi hammaddeleri olan kömür ve çelik sektörünü güçlendirmek ve bunları uluslararası bir otorite ile kontrol ederek barışı sürdürmek amacıyla 18 Nisan 1951 tarihinde kurulan Avrupa Kömür ve Çelik Topluluğu oluşturmaktadır. Bu topluluk, Almanya, Fransa, Belçika, Hollanda, Lüksemburg ve İtalya arasında imzalanan

Hakan Sevgin, Pamukkale Üniversitesi, hsevgin09@hotmail.com

Yrd. Doç. Dr. Nilsen Kundakc1, Pamukkale Üniversitesi, nkarakasoglu@pau.edu.tr 
Paris Antlaşması (1951) ile kurulmuştur. Bu ülkeler tarafından 25 Mart 1957 tarihinde imzalanan Roma Antlaşması ile Avrupa Atom Enerjisi Topluluğu ve Avrupa Ekonomik Topluluğu (AET) kurulmuştur (Esen, 2012, s.1-2).

1958 yılında Roma Antlaşmasının yürürlüğe girmesi ile üye olan ülkeler arasında öncelikle gümrük birliğinin sağlanması öngörülmüştür. Gümrük birliği 1 Temmuz 1968 yılında yürürlüğe girmiştir. Roma Antlaşmasının yapılması, Avrupa Toplulukları̉nın ekonomik sıkıntılarını gidermede yetersiz kalmıștır. Bu durumda, 1 Temmuz 1987 yılında Avrupa Tek Senedi yürürlüğe girmiştir (Tatoğlu, 2006, s.22). Avrupa Tek Senedi'nin amacı, AB ye üye olan ülkeler arasında var olan ekonomik engelleri ortadan kaldırmak, uyumu arttırmak ve AB'ye üye olan ülkeler arasında rekabet alanı oluşturmaktı.

AB Antlaşması olarak da bilinen Maastricht Kriterleri, 9-10 Aralık 1991 tarihinde kabul edilmiştir. Antlaşma metni ise 1 Ocak 1993 yllında 12 ülkenin devlet başkanları tarafından imzalanarak yürürlüğe girmiştir. Böylece var olan AET, AB adını almıştır (İnan, 2005, s.74). Maastricht Anlaşması'nın Ekonomik ve Parasal Birliğinin (EPB) aşamaları, belirli bir süreçte ekonomik ve parasal politikalar ile bunların gerektirdiği kurumsal değişiklikler detaylı olarak düzenlenmiştir (Özden, 2011, s.226). Bu düzenlemeler ve EPB ile üye ülke ekonomileri arasındaki farklılıkların giderilebilmesi öngörülmüştür.

$\mathrm{AB}$, yirmi sekiz üye ülkeden oluşan ve toprakların çoğunluğu Avrupa kıtası üzerinde bulunan ekonomik ve siyasi bir teşkilattır. $A B$, üye ve aday ülkelerden bazı kriterleri yerine getirmelerini bekler. Kopenhag kriterleri, AB'ye tam üye olmak için yerine getirilmesi gerekirken, Maastricht yakınlaşma kriterleri hali hazırda $\mathrm{AB}$ üyesi olan ülkelerin $\mathrm{EPB}$ alanına dâhil olmak için gerekli kriterlerdir. AB'ye üye olmak için karşılanması gereken üç kriter; siyasi, ekonomik ve uyum kriterleri olarak bilinmektedir. Kopenhag ekonomik kriterleri açısından aday ülke ekonomisi, işleyen bir serbest piyasa ekonomisine ve $\mathrm{AB}$ içinde rekabet baskısına dayanabilme gücüne sahip olma açısından değerlendirilmektedir. $\mathrm{AB}$ üyesi ülkelerin EPB alanına dâhil olabilmek için yerine getirmeleri gereken ekonomik kriterler ise Maastricht yakınlaşma kriterleri olarak isimlendirilmekte ve enflasyon, faiz, döviz kuru ve devletin finansal durum kriterle- rinden (bütçe ve borç kriteri) oluşmaktadır (Akçay, 2008, s.11). Maastricht kriterleri şu şekilde sıralanabilir:

- AB’ye üye olan ülkelerin, bütçe açı̆̆ının GSYİH 'sına oranı \% 3'ü geçmemelidir.

- AB'ye üye olan ülkelerin, devlet borçlarının GSYİH 'sına oranı \% 60'1 geçmemelidir.

- AB'ye üye olan ülkelerin en düşük enflasyona sahip olan üç ülkenin yıllık enflasyon oranları ortalaması ile ilgili üye ülke enflasyon oranı arasındaki fark 1,5 puanı geçmemelidir.

- Herhangi bir üye ülkede uygulanan uzun vadeli faiz oranları 12 aylık dönem itibariyle, fiyat istikrarı alanında en yüksek performansı gösteren 3 ülkenin faiz oranı 2 puanı aşmayacaktır.

- Son 2 yıl içinde, üye olan ülkenin parası diğer bir üye ülkenin parası karşısında devalüe edilmiş olmamalıdır (Günay ve Özen, 2002, s.73-74).

AB'ye üye ve aday ülkelerin mevcut ekonomik performanslarının değerlendirilmesi, topluluk içinde politikaların belirlenmesinde yol gösterici olabilecektir. Ülkeler arasındaki farklılıklar ortaya koyulmaya çalışılarak yapılması gereken yapısal düzenlemeler buna göre belirlenebilecektir.

Performans, bir eylemi, süreci ya da operasyonu gerçekleştiren kişinin veya nesnenin bir standart doğrultusunda ölçülen becerileri, yetkinliği veya etkinliği, üretkenliği veya başarıyı gerçekleştirme kalitesidir. Performans ölçümleri yardımıyla, faaliyetlerinin istenen amaçlara ulaşıp ulaşmadığı, hizmetlerinin verimli, etkin, ekonomik ve karlı bir düzeyde gerçekleştirilip gerçekleştirilmediği ortaya konabilmektedir. Ülkelerin performans ölçümü ise, kaynak kullanıminda ekonomiklik, etkenlik, verimlilik ve karlılık gibi ilkelere ne düzeyde ulaşılabildiğinin ölçülmesi, sorunların tespiti ve iyileştirme için gerekli önlemlerin alınmasını içerir. Özetle, performans ülkelerin mali, beşeri ve fiziki kaynaklarını amaçları doğrultusunda ne kadar etkin ve verimli kullandığını belirleyen bir kavramdır (Özden, 2012, s.56).

Ülkeler arasındaki rekabetin yoğun yaşandığı günümüzde, ülkelerin ekonomik performanslarını geliştirebilmeleri için öncelikle mevcut durumları ve diğer 
ülkeler arasındaki konumları hakkında fikir sahibi olmaları fayda sağlayabilir. Bu bağlamda, ülkeler arasında ekonomik performanslara göre sıralamaya ulaşmada çok sayıda birbirinden bağımsız ve farklı şekillerde ifade edilen kriterler dikkate alındığından ÇKKV yöntemlerini kullanmak uygun olacaktır. ÇKKV yöntemlerini kullanmaktaki amaç alternatif ve kriter sayılarının fazla olduğu durumlarda karar verme mekanizmasını kontrol altında tutabilmek ve alternatifler arasındaki sıralamayı mümkün olduğu kadar kolay ve çabuk elde etmektir (Ball, 2005, s.12). Literatürde $A B$ 'ye üye ve aday olan ülkelerin performanslarına göre değerlendirmeyi amaçlayan çalı̧̧malar yer almaktadır. Karabulut vd. (2008) Türkiye ve AB'ne üye ülkelerin 2001-2005 y1lları arasındaki makroekonomik performans düzeylerini karşılaştırmalı veri seti kullanarak veri zarflama analizi yöntemi ile analiz etmiştir. Özden (2011), 2009 yllı verilerine göre, $A B$ ’ye üye ve aday olan ülkelerin TOPSIS yöntemiyle performanslarını değerlendirmiștir. Tekin (2011), veri zarflama analizi yöntemi ile 2009 yılı ekonomik verilerini kullanarak $\mathrm{AB}$ ülkeleri ve aday ülke Türkiye’nin göreli finansal etkinliklerini ölçmüştür. Özden (2012), 2010 y1lı ekonomik göstergelerinden yararlanarak AB'ye üye ve aday ülkelerden Türkiye’nin VIKOR yöntemi ile sıralamalarına ulaşmıştır. Genç ve Masca (2013), TOPSIS ve PROMETHEE yöntemlerini kullanarak $\mathrm{AB}$ üye ülkeleri ve Türkiye’nin bazı ekonomik kriterlere göre performans sıralamalarını ayrı ayrı elde etmiş ve sonuçları karşılaştırmıştır. Çakır ve Perçin (2013), AB üyesi ve AB'ye aday ülkelerin Bütünleşik Entropi Ağırlık-TOPSIS yöntemi ile Ar-Ge performanslarının ölçümünü yapmıştır. Urfalığlu ve Genç (2013), ELECTRE, PROMETHEE ve TOPSIS yöntemleri ile $A B$ üye ve aday ülke Türkiye’nin 2010 yılı verilerini kullanarak ekonomik performanslarını karşılaştırmıştır.

Ayrıca, Jesionowski (1996), ekonomik rekabeti ölçmek için benzerlik ve uzaklığa dayalı yöntemler önererek, $\mathrm{AB}$ üyesi ülkelerin ekonomik rekabet güçlerine göre sıralamalarına ulaşmıştır. Baležentis vd. (2010), MULTIMOORA yöntemi ile yapısal göstergelerden faydalanarak Litvanya ve diğer Baltık ülkelerinin $\mathrm{AB}$ üyesi ülkeler arasındaki konumunu ortaya koymuştur. Šoltés (2012), rekabet gücünü ölçen GSYİH artışı ve üretkenlik gibi ölçütlerden yararlanarak Slovakya’nın diğer $\mathrm{AB}$ üyesi ülkeler arasındaki yerini belirlemeye çalışmış ve ülkeler arasında rekabetçi konumlarına göre bir sıralamaya ulaşmıştır. Alptekin (2015), Ent- ropi ve TOPSIS yöntemlerinden yararlanarak AB'ye üye ülkeler ve Türkiye’nin sürdürülebilir kalkınma göstergelerine göre sıralamalarını elde etmiştir.

$\mathrm{Bu}$ çalışmada ise, $\mathrm{AB}$ 'ye üye olan ülkelerin ve Türkiye'nin 2013 yılı verileri kullanılarak MOORA ve TOPSIS yöntemleri ile Maastricht kriterlerine esas olan ekonomik göstergelere göre sıralamalarını elde etmek amaçlanmıştır. Çalışmanın birinci bölümünde konuya ilişkin bir giriş yapıldıktan sonra ikinci ve üçüncü bölümlerde sırasıyla TOPSIS ve MOORA yöntemleri açıklanmıştır. Dördüncü bölümde uygulamaya yer verilmiş, TOPSIS ve MOORA yöntemleri kullanılarak $\mathrm{AB}$ ülkeleri ve aday olan toplam 29 ülkenin performanslarına göre sıralamalarına ulaşılmıştır. Ayrıca, iki yöntem sonucu elde edilen sonuçların karşılaştırılmasına da yer verilmiştir. Beşinci bölümde sonuç ve öneriler sunulmuştur.

\section{TOPSIS Yöntemi}

TOPSIS Yöntemi (Technique for Order Preference by Similarity to Ideal Solution), 1981 yllinda Hwang ve Yoon tarafından önerilmiştir. ÇKKV yöntemlerinden biri olan TOPSIS yönteminde, " tane alternatif ve " tane kriterden oluşan ÇKKV problemi boyutlu uzayda nokta ile gösterilebilir (Triantaphyllou, 2000, s.18). Bu yöntem, seçilen alternatifin, pozitif ideal çözüme en yakın (PIS), negatif ideal çözüme (NIS) en uzak mesafede olması esasına dayanır (Lai vd., 1994, s.487).

TOPSIS yönteminde, belirli kriterlerle alternatif seçeneklerin ideal çözüme uzaklıkları değerlendirilerek sıralama yapılmaktadır. Burada, ideal çözüm için gerekli olan yakınlık hesaplanırken, hem pozitif ideal çözüme, hem de negatif ideal çözüme uzaklık dikkate alınmaktadır (Wang ve Elhag, 2005, s.310). Tüm alternatiflerin pozitif ideal ve negatif ideal çözüme olan uzaklıkları öklid uzaklığı yardımıyla bulunur. TOPSIS yöntemi, pozitif ideal çözüme en kısa olan alternatifi en iyi alternatif olarak kabul ettiğinden, görece uzaklıkların karşılaştırılmasıyla tüm alternatifler sıralanabilmektedir (Tong vd., 2005, s.409).

TOPSIS yöntemi ÇKKV yöntemlerinden biri olarak ekonomi veya yönetim problemleri, sermaye yatırımi, pazarlama stratejisi, muhasebe ve finans, kaynak tahsisi, veri tabanı seçimi, kamu sektörü, karar destek, planlama, portföy seçimi, risk analizi, üretim, makroekonomik planlama, pazarlama, ürün tasarımı, tesis 
yeri seçimi, politika/strateji, çevresel kararlar, pazar seçimi, sağlık, ulaştırma, silah kontrolü, bilgisayar ve bilgi seçimi, eğitim gibi alanlarda kullanılabilmektedir (Özer, 2010, s.105).

TOPSIS yöntemi 10 adımdan meydana gelen bir çözüm sürecine sahiptir. TOPSIS yönteminin adımları (Triantaphyllou, 2000, s.18-20; Chang vd., 2005, s.6667; Özden, 2011, s.220; Yurdakul ve İç, 2003, s.11-12) şu şekilde özetlenebilir:

1. Adım: Problemin tanımlanması

TOPSIS yönteminde, öncelikle karar verici/vericilerin istediği hedefe ulaşabilmesi için seçime veya sıralamaya konu olan problem tanımlanır.
2. Adım: Kriterler ve alternatiflerin belirlenmesi $\mathrm{Bu}$ adımda, problemle ilgili olarak hedefe ulaşmak için dikkate alınması gereken kriterler ve sıralanacak olan alternatifler belirlenir.

\section{Adım: Karar matrisinin oluşturulması}

Karar matrisinin sütunlarında karar vermede kullanılacak değerlendirme kriterleri, satırlarında ise üstünlükleri sıralanmak istenen alternatifler yer alır (Ünal, 2008: 65). A matrisi karar vericiler tarafından belirlenen başlangıç matrisidir.

$$
A=\left[\begin{array}{ccc}
x_{11} & x_{12} \cdots & x_{1 n} \\
\vdots & \ddots & \vdots \\
x_{m 1} & x_{m 2} \cdots & x_{m n}
\end{array}\right]
$$

Tablo 1. Karar matrisi (A)

\begin{tabular}{|l|l|l|l|l|}
\hline & \multicolumn{5}{|c|}{ Kriterler } \\
\hline Alternatifler & $K_{1}$ & $K_{2}$ & $\ldots$ & $K_{n}$ \\
\hline $\boldsymbol{A}_{\mathbf{1}}$ & $x_{11}$ & $x_{12}$ & $\ldots$ & $x_{1 n}$ \\
\hline $\boldsymbol{A}_{\mathbf{2}}$ & $x_{21}$ & $x_{22}$ & $\ldots$ & $x_{2 n}$ \\
\hline$\ldots$ & $\ldots$ & $\ldots$ & $\ldots$ & $\ldots$ \\
\hline $\boldsymbol{A}_{\boldsymbol{m}}$ & $\boldsymbol{x}_{\boldsymbol{m} \mathbf{1}}$ & $\boldsymbol{x}_{\boldsymbol{m} 2}$ & $\ldots$ & $\boldsymbol{x}_{\boldsymbol{m}}$ \\
\hline
\end{tabular}

Tablo 1'de gösterildiği gibi $A$ karar matrisi tablo şeklinde de gösterilebilir. Karar matrisindeki ve Tablo 1'deki $A$ matrisinde $m$ alternatif sayısını, $n$ kriter sayısinı belirtmektedir.

\section{Adım: Karar matrisinin normalize edilmesi}

TOPSIS yönteminde, normalize edilmiş karar matrisi Eşitlik (1) yardımıyla $A$ matrisinin elemanlarından yararlanarak elde edilir ve $R$ ile gösterilir. Burada, $i$. alternatifin $j$. kriter için normalize edilmiş değeri ile ifade edilir.

$$
\begin{aligned}
x_{i j}^{*} & =\frac{x_{i j}}{\sqrt{\Sigma_{i=1}^{m} x_{i j}^{2}}} \quad i=1,2, \ldots, m, j=1,2 \ldots ., n \\
R & =\left[\begin{array}{ccc}
x_{11}^{*} & x_{12}^{*} \cdots & x_{1 n}^{*} \\
\vdots & \ddots & \vdots \\
x_{m 1}^{*} & x_{m 2}^{*} \cdots & x_{m n}^{*}
\end{array}\right]
\end{aligned}
$$

\section{Adım: Kriterlerin ağırlıklarının belirlenmesi} Alternatiflerin sıralanması için, karar vericiler tarafından kriterlerin karar üzerindeki ağırlıkları farklı olabilmektedir. Ayrıca kriterlere verilen ağırlıklar kişiden kişiye de değişebilmektedir. Bu sebeple ağır- lıkların iyi bir şekilde belirlenebilmesi için uzman kişilerin görüşlerine başvurulabilir. Bu ağırlıklar birden çok kişi tarafından belirleniyorsa kişilerin tercihlerinin geometrik ortalaması veya aritmetik ortalaması kullanılabilmektedir. $n$ kriter sayısı olduğunda, karar vericiler tarafından belirlenen her bir kritere karşılık gelen kriter ağıllıkları $v_{j}=\left(w_{1}, w_{2}, \ldots, w_{n}\right)$ şeklinde ifade edilir. Burada kriter ağırlıklarının toplamı l'e eşittir.

6. Adım: Ağırlıklı normalize karar matrisinin elde edilmesi:

Ağırlıklı normalize karar matrisi ( $V)$, normalize karar matrisindeki her bir değerin, belirlenen ilgili sütundaki kriterlere ait ağırlıklar $\left(w_{1}, w_{2}, w_{3}, \ldots, w_{n}\right)$ ile çarpılmasıyla elde edilir. Ağırlıklı normalize karar matrisi değerleri $\left(v_{i j}\right)$;

$v_{i j}=w_{i j} \cdot x_{i j}^{*} \quad i=1, \ldots, m \quad j=1, \ldots, n$

formülüyle hesaplanır ve matris gösterimi;

$V=\left[\begin{array}{ccc}v_{11} & v_{12} \cdots & v_{1 n} \\ \vdots & \ddots & \vdots \\ v_{m 1} & v_{m 2} \cdots & v_{m n}\end{array}\right]$

şeklinde ifade edilir. 
7. Adım: Pozitif ve negatif ideal çözümlerin bulunması Pozitif ideal çözüm $A^{+}$, negatif ideal çözüm ise $A^{-}$ sembolleri ile gösterilir. Pozitif ideal çözüm olarak ifade edilen en iyi çözüm, fayda kriterini maksimize eden maliyet kriterini ise minimize eden çözümdür. Negatif ideal çözüm ise fayda kriterini minimize eden maliyet kriterini ise maksimize eden çözümdür. Burada, negatif ideal çözüme en uzak mesafede olan alternatifin aynı zamanda pozitif ideal çözüme en yakın mesafede olan alternatif olduğu varsayılmaktadır. Bazı durumlarda bu sağlanamayabilir. Örneğin Şekil 1'deki $A_{1}$ ve $A_{2}$ gibi iki alternatif göz önüne alınırsa $A_{2}, A^{+}$ya en yakın noktadır fakat $A_{1}$ de aynı zamanda $A^{-}$'den en uzak noktadadır.

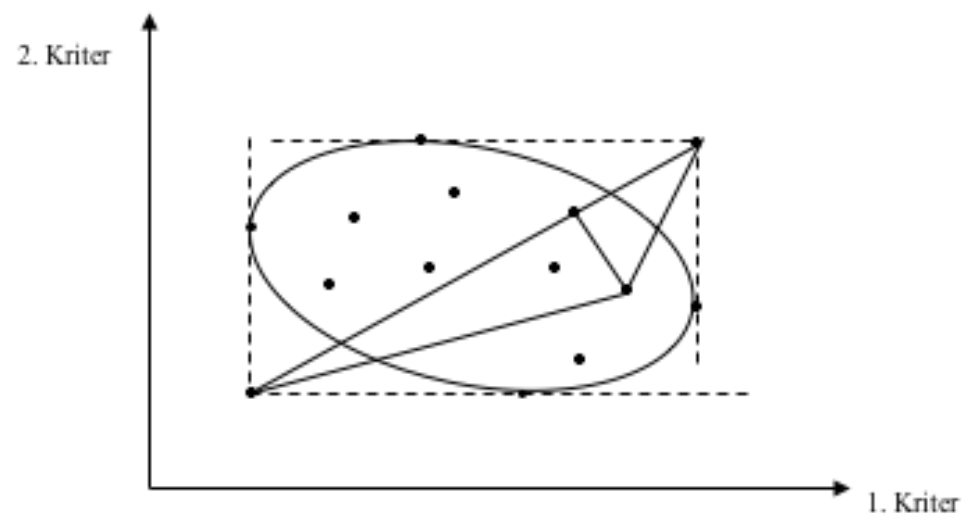

Şekil 1. İki Boyutlu Uzayda Pozitif ve Negatif Ideal Çözümler Kümesi

$A^{+}$ve $A^{-}$ağırlıklı normalize matrisin elemanları arasından seçilir. $J_{1}$ fayda kriterleri kümesini, $J_{2}$ ise maliyet kriterleri kümesini göstermek üzere, pozitif ideal çözüm ve negatif ideal çözüm aşağıdaki gibi bulunur:

$$
\begin{gathered}
A^{+}=\left\{v_{1}^{+}, v_{2}^{+}, \ldots v_{j}^{+}, \ldots v_{n}^{+}\right\} \\
=\left\{\left(\max _{i} v_{i j} \mid j \in J_{1}\right),\left(\min _{i} v_{i j} \mid j \in J_{2}\right) \mid i \in 1, \ldots m\right\} \\
A^{-}=\left\{v_{1}^{-}, v_{2}^{-}, \ldots v_{j}^{-}, \ldots v_{n}^{-}\right\} \\
=\left\{\left(\min _{i} v_{i j} \mid j \in J_{1}\right),\left(\max _{i} v_{i j} \mid j \in J_{2}\right) \mid i \in 1, \ldots m\right\}
\end{gathered}
$$

8.Adım: Ayırma ölçümlerinin hesaplanması Ayırma ölçüsü, pozitif ideal çözüme ya da negatif ideal çözüme olan uzaklığı ifade eder. Tüm alternatiflerin pozitif ideal çözümden öklid anlayışına göre uzaklığı $S_{i}^{+}$ile gösterilir ve Eşitlik (7) yardımıyla şu şekilde hesaplanır:

$$
S_{i}^{+}=\sqrt{\sum_{i=1}^{n}\left(v_{i j}-v_{j}^{+}\right)^{2}} \quad i=1, \ldots, m
$$

$S_{i}^{-}$ise oluşturulan tüm alternatifler içinde negatif ideal çözümden öklid uzaklığını göstermektedir ve Eşitlik (8) yardımıyla şu şekilde hesaplanır:

$S_{i}^{-}=\sqrt{\sum_{i=1}^{n}\left(v_{i j}-v_{j}^{-}\right)^{2}} \quad i=1, \ldots, m$

9. Adım: İdeal çözüme göreli yakınlığın hesaplanması Bazen seçilen alternatif ya da karar PIS’a en yakın olmasına rağmen NIS’a diğer bazı alternatiflere göre daha yakın olabilir. PIS’a dayanan uzlaştırıcı çözüm, NIS’a dayanan çözüm ile aynı olmayabilir. Bu gibi durumlarda iki uzaklığı aynı anda dikkate almak gerekir (Lai vd., 1994, s.489). Bu yüzden, ideal çözüme göreli yakınlık hesaplanır. İdeal çözüme göreli yakınlık, bu uzaklıkların ikisini de göz önünde bulundurmaktadır. Bu tanıma göre en büyük ideal çözüme benzerliğe sahip olan alternatif, en iyi alternatif olarak seçilecektir (Gürbüz vd., 2006, s.428). 
Tüm karar noktalarının ideal çözüme göreli yakınlığ 1 $C_{i}^{*}$ değerinin hesaplanmasında pozitif ideal ve negatif ideal ayrım ölçülerinden yararlanılır. Bu ölçüt, negatif ideal ayrım ölçüsünün toplam ayrım ölçüsü içindeki payıdır. İdeal çözüme göreli yakınlık değerinin hesaplanması Eşitlik (9) yardımıyla yapılır.

$C_{i}^{*}=\frac{S_{i}^{-}}{S_{i}^{+}+S_{i}^{-}} \quad i=1, \ldots, m$

Burada $C_{i}^{*}$ değeri $0<C_{i}^{*}<1$ aralığında değer alır ve $C_{i}^{*}$ $=1$ ilgili karar noktasının pozitif ideal çözüme, $C_{i}^{*}=$ 0 ilgili karar noktasının negatif ideal çözüme mutlak yakınlığını gösterir.

10. Adım: Tercih sıralamasının belirlenmesi

$C_{i}^{*}$ değerinin büyüklüğ̈üne göre alternatifler arasında sıralama yapılır ve en yüksek $C_{i}^{*}$ değerine sahip alternatif seçilir

\section{MOORA Yöntemi}

MOORA (Multi Objective and Optimization on the Basis of Ratio Analysis), ilk kez 2006 yilında Brauers ve Zavadskas tarafından önerilen oransal analize dayalı bir çok amaçlı optimizasyon yöntemidir. Diğer ÇKKV yöntemlerine göre yeni bir yöntem olan MOORA, literatürde farklı alanlara uygulanmıştır. Brauers ve Zavadskas, (2006), özelleștirme uygulamalarının değerlendirilmesinde, Brauers, Zavadskas, Turskis ve Vilutiene (2008) müteahhit firmalarin siralanmasında, Brauers Zavadskas, Peldschus ve Turskis (2008) yol tasarım alternatiflerinin değerlendirilmesinde, Kalibatas ve Turkis (2008) en uygun oturma odası koşullarına karar vermede, Brauers, Ginevicius (2009) ve Brauers, Ginevicius, Podvezko (2010) bölgesel büyüme çalışmalarında, Brauers ve Zavadskas (2010) proje yönetiminde, Kracka, Brauers ve Zavadskas (2010) binalarda isı kaybina karşıllk farklı pencere ve duvar tasarım alternatifleri arasında seçim yapmada, Gadakh (2011) ögütme işleminin parametrik optimizasyonunda, Archana ve Sujatha (2012) kablosuz ağların seçiminde, Karaca (2011) proje yönetiminde kritik yolun belirlenmesinde, Önay ve Çetin (2012) turistik yerlerin popülaritesinin belirlenmesinde, Dey, Bairagi, Sarkar ve Sanyal, (2012) tedarik zinciri seçiminde, Mandal ve Sarkar,
(2012) zeki üretim sistemlerinin seçiminde, Balezantis, Balezantis, ve Brauers (2012) personel seçiminde, Görener, Dinçer ve Hacıoğlu (2013) banka şubeleri için yer seçiminde, Tepe ve Görener (2014) personel seçiminde MOORA yönteminden yararlanmışlardır.

MOORA yönteminin ilk adımını, TOPSIS yönteminde olduğu gibi problemin tanımlanması oluşturur. Daha sonra kriterler ve alternatifler belirlenir ve karar matrisi oluşturulur. MOORA yöntemi, oran yöntemi ve referans nokta yöntemi olmak üzere iki yaklaşıma sahiptir (Brauers, Zavadskas, Turskis ve Vilutiene, 2008, s.248).

\section{Oran Yöntemi}

Oran yönteminde, karar matrisi oluşturulduktan sonra Eşitlik (1) yardımıyla her bir alternatifin karelerinin toplamının karekökü ile kriterler bölünerek normalizasyon işlemi yapılır. $x_{i j}^{*} \in[0,1]$ olmak üzere; $i$. alternatifin, $j$. kriter açısından normalize edilmiş performans ölçüm değeridir.

Normalize karar matrisi elde edildikten sonra, kriterler maksimum veya minimum olmalarına göre belirlenerek, maksimum kriterlere ait toplam değer ve minimum kriterlere ait toplam değer ayrı ayrı elde edilir. Daha sonra Eşitlik (10)'da verildiği gibi elde edilen bu değerlerin farkı alınarak her bir alternatif için tek bir değer elde edilir:

$$
y_{i}^{*}=\sum_{j=1}^{g} x_{j}^{*}-\sum_{j=g+1}^{n} x_{j}^{*}
$$

Bu eşitlikte, $j=1,2, \ldots, g$ maksimize edilecek kriterler, $j=g+1, g+2, \ldots, n$ ise minimize edilecek kriterlerdir. $y_{i}^{*} ; i$. alternatifin tüm kriterlere göre normalize edilmiş değeridir. Son olarak, $y_{i}^{* \prime}$ ler büyükten küçüğe doğru sıralanarak, alternatifler arasındaki sıralamaya ulaşılır.

\section{Referans Nokta Yöntemi}

Referans nokta yönteminde, oran yöntemine ek olarak her kriter için referans noktalar ( $r_{j}^{\prime}$ ler) belirlenir. Referans noktalar belirlenirken, amaç maksimizasyon ise maksimum noktalar, amaç minimizayon ise minimum noktalar alınır. Belirlenen bu noktaların her $x_{\ddot{y}}^{*}$ ile olan uzaklıkları Eşitlik (11) yardımıyla bulunur. 
$r_{j}-x_{j}^{*}$

$r_{j}, j$. kriterin referans noktasını göstermektedir. Oluşturulan yeni matrise Eşitlik (12)'te gösterilen “Tchebycheff Min-Maks Metrik” işlemi uygulanır ve böylece sıralamaya ulaşılır (Önay, 2014, s.248).

$\min _{i}\left\{\operatorname{maks}_{j}\left(\left|r_{j}-x_{j}^{*}\right|\right)\right\}$

Bazı durumlarda, kriterler farklı öneme sahip olabileceğinden, kriterlere farklı ağırlıklar atanabilir. $\mathrm{Bu}$ durumda, oran yönteminde kritere ait ağırlık, bir alternatifin normalize edilmiş değeri ile çarpılır.

$\ddot{y}_{i}^{*}=\sum_{j=1}^{g} w_{j} x_{j}^{*}-\sum_{j=g+1}^{n} w_{j} x_{j}^{*}$

Eşitlik (13)'te $w_{j}$, kriterinin sahip olduğu ağırlığ 1 ifade eder ve kriter ağırlıklarının toplamı 1'e eşittir. Ayrıca, $j=1,2, \ldots, g$ maksimize edilecek kriterleri; $j=$ $g+1, g+2, \ldots, n$ minimize edilecek kriterleri göstermektedir. $\ddot{y}_{i}^{*} ; i$. alternatifin ağırlığıyla tüm kriterlere göre normalleştirilmiş değerlendirmesidir. Referans nokta yönteminde ise önem ağırlıkları Eşitlik (12)'de $\left|w_{j} r_{j}-w_{j} x_{j}^{*}\right|$ şeklinde yer alır (Önay, 2014, s.248).

\section{Uygulama}

Bu çalışmada, AB'ye üye olan 28 ülkenin ve aday olma aşamasındaki Türkiye’nin 2013 verileriyle, Maastricht kriterlerine esas olan ekonomik göstergeler kullanılarak ÇKKV yöntemlerinden olan TOPSIS ve MOORA yöntemleriyle sıralamalarına ulaşılmış ve elde edilen bulgular çerçevesinde değerlendirme yapılmıştır. Ekonomik performansları belirlemek için kriter olarak kullanılan göstergelere ilişkin veriler; EuroStat ve TCMB'nin web sitelerinden alınmıştır. Hesaplamalarda Microsoft Excel kullanılmıştır.

AB’ye üye olan 28 ülke ve Türkiye’nin bulunduğu 29 alternatif bulunmaktadır. Bu ülkeler aşağıdaki Tablo 2'de yer almaktadır.

Tablo 2. Alternatifler

\begin{tabular}{|c|c|c|c|c|c|}
\hline $\begin{array}{l}\text { Kurucular } \\
\text { (1958) }\end{array}$ & $\begin{array}{l}\text { 2004'ten önce } \\
\text { Katılanlar }\end{array}$ & $\begin{array}{l}\text { 2004'te } \\
\text { Katılanlar }\end{array}$ & $\begin{array}{l}2007 \text { 'de } \\
\text { Katılanlar }\end{array}$ & $\begin{array}{l}\text { 2013'te } \\
\text { Katılan }\end{array}$ & Aday Ülke \\
\hline $\begin{array}{l}\text { Almanya } \\
\text { Belçika } \\
\text { Fransa } \\
\text { Hollanda } \\
\text { İtalya } \\
\text { Lüksemburg }\end{array}$ & $\begin{array}{l}\text { Avusturya } \\
\text { Danimarka } \\
\text { Finlandiya } \\
\text { İngiltere } \\
\text { İrlanda } \\
\text { İspanya } \\
\text { İsveç } \\
\text { Portekiz } \\
\text { Yunanistan }\end{array}$ & $\begin{array}{l}\text { Çek Cum. } \\
\text { Estonya } \\
\text { Güney Kıbrıs } \\
\text { Letonya } \\
\text { Litvanya } \\
\text { Macaristan } \\
\text { Malta } \\
\text { Polonya } \\
\text { Slovakya } \\
\text { Slovenya }\end{array}$ & $\begin{array}{l}\text { Bulgaristan } \\
\text { Romanya }\end{array}$ & Hirvatistan & Türkiye \\
\hline
\end{tabular}

Çalışmada esas alınacak alternatiflerin belirlenmesinin ardından ülkelerin ekonomik performanslarına göre sıralamasında kullanılacak kriterler Tablo 3'te görüldüğü gibi belirlenmiştir. 
Tablo 3. Kriterler

\begin{tabular}{ll}
\hline Kriterler \\
\hline $\mathbf{K}_{\mathbf{1}}$ & Kişi Başına Milli Gelir (GSYİH/Nüfus) \\
$\mathbf{K}_{2}$ & Enflasyon \\
$\mathbf{K}_{3}$ & İşsizlik \\
$\mathbf{K}_{4}$ & İhracat/Ithalat \\
$\mathbf{K}_{5}$ & Kamu Borçları/GSYİH \\
$\mathbf{K}_{6}$ & Bütçe Açığı/GSYİH \\
\hline
\end{tabular}

Çalışmada kullanılacak kriterlerler, 6 makroekonomik göstergeden oluşmaktadır. Bu kriterler belirlenirken Maastricht Antlaşması ile konulan mali kriterler temelinde, ülkelerin ekonomik performansını gösteren en önemli makro ekonomik göstergeler dikkate alınmıştır. Seçilen kriterler kısaca aşağıdaki gibi tanımlanabilir:
İssizlik Oranı: İşsizlik, çalışma gücünde ve arzusunda olan ve cari ücretten çalışmaya razı olup da iş bulamayan işgücünün varlığıdır. İşgücü ise, çalışma kabiliyeti ve yeteneğine sahip nüfustur. İşsizlik oranı ise, iş bulamayan nüfusun toplam işgücüne oranı olarak tanımlanabilir.

Kamu Borçları: Bir ülkenin kamu kesiminin borç stoku, o ülkenin kamu kesiminde yer alan KİT'ler d1şındaki birimlerin iç ve dış borçlarının toplam miktarını kapsar. Kamu kesimi borç yükü ise, kamu kesimi borç stokunun o dönemdeki GSYİH'ya oranı olarak ifade edilir.

Gayri Safi Yurt İçi Hâsıla (GSYİH) : Bir ülke sınırları içerisinde belirli bir zaman içinde, üretilen tüm nihai mal ve hizmetlerin para birimi cinsinden değeridir.

Tablo 4. Karar matrisi

\begin{tabular}{|c|c|c|c|c|c|c|}
\hline & \multicolumn{6}{|c|}{ Kriterler } \\
\hline Alternatifler & $\overline{K_{1}}$ & $\mathbf{K}_{2}$ & $\mathbf{K}_{3}$ & $\mathbf{K}_{4}$ & $\overline{K_{5}}$ & $\overline{\mathbf{K}_{6}}$ \\
\hline Belçika & 35600 & 1,2 & 8,4 & 1,016 & 101,5 & $-2,6$ \\
\hline Bulgaristan & 5600 & 0,4 & 13 & 0,992 & 18,9 & $-1,5$ \\
\hline Çek Cum. & 15000 & 1,4 & 7 & 1,081 & 46 & $-1,5$ \\
\hline Danimarka & 45100 & 0,5 & 7 & 1,118 & 44,5 & $-0,8$ \\
\hline Almanya & 34200 & 1,6 & 5,2 & 1,146 & 78,4 & 0 \\
\hline Estonya & 14200 & 3,2 & 8,6 & 1,017 & 10 & $-0,2$ \\
\hline İrlanda & 38000 & 0,5 & 13,1 & 1,246 & 123,7 & $-7,2$ \\
\hline Yunanistan & 16500 & $-0,9$ & 27,5 & 0,911 & 175,1 & $-12,7$ \\
\hline İspanya & 22500 & 1,5 & 26,1 & 1,121 & 93,9 & $-7,1$ \\
\hline Fransa & 32100 & 1 & 10,3 & 0,950 & 93,5 & $-4,3$ \\
\hline Hirvatistan & 10200 & 2,3 & 17,3 & 1,011 & 67,1 & $-4,9$ \\
\hline İtalya & 26500 & 1,3 & 12,1 & 1,088 & 132,6 & -3 \\
\hline Güney K. & 21000 & 0,4 & 15,9 & 1,051 & 111,7 & $-5,4$ \\
\hline Letonya & 11600 & 0 & 11,9 & 0,953 & 38,1 & -1 \\
\hline Litvanya & 11800 & 1,2 & 11,8 & 1,015 & 39,4 & $-2,2$ \\
\hline Lüksemburg & 83100 & 1,7 & 5,9 & 1,209 & 23,1 & 0,1 \\
\hline Macaristan & 10200 & 1,7 & 10,2 & 1,094 & 79,2 & $-2,2$ \\
\hline Malta & 17900 & 1 & 6,4 & 1,037 & 73 & $-2,8$ \\
\hline Hollanda & 38300 & 2,6 & 7,3 & 1,142 & 73,5 & $-2,5$ \\
\hline Avusturya & 38100 & 2,1 & 5,4 & 1,071 & 74,5 & $-1,5$ \\
\hline Polonya & 10300 & 0,8 & 10,3 & 1,043 & 57 & $-4,3$ \\
\hline Portekiz & 16400 & 0,4 & 16,4 & 1,026 & 129 & $-4,9$ \\
\hline Romanya & 7200 & 3,2 & 7,1 & 0,983 & 38,4 & $-2,3$ \\
\hline Slovenya & 17500 & 1,9 & 10,1 & 1,088 & 71,7 & $-14,7$ \\
\hline Slovakya & 13600 & 1,5 & 14,2 & 1,051 & 55,4 & $-2,8$ \\
\hline Finlandiya & 37100 & 2,2 & 8,2 & 0,978 & 57 & $-2,1$ \\
\hline İsveç & 45500 & 0,4 & 8 & 1,129 & 40,6 & $-1,1$ \\
\hline İngiltere & 31500 & 2,6 & 7,6 & 0,939 & 90,6 & $-5,8$ \\
\hline Türkiye & 6630 & 7,5 & 9 & 0,603 & 36 & $-1,9$ \\
\hline
\end{tabular}


İhracatın İthalatı Karşılama Oranı: İhracat, bir ülke sınırları içerisinde serbest dolaşımda bulunan malların ve hizmetlerin başka ülkelere satılması olarak tanımlanabilir. İthalat ise, yurtdıșında üretilmiș malların, ülkedeki alıcılar tarafından satın alınmasıdır. İhracatın yüksek ithalatın düşük olması durumunda, ihracatın ithalatı karşılama oranı yüksek olacaktır.

Enflasyon Orani: Fiyatlar genel düzeyinin sürekli ve hızlı olarak yükselmesi olarak tanımlanabilir. Enflasyon, fiyatlar genel düzeyindeki devamlı bir artış sürecinin yanında paranın değerindeki sürekli bir düşmeyi de ifade eder.
Bütçe Açı̆̆ı: Konsolide bütçe harcamalarının, konsolide bütçe gelirlerinden fazla olması halinde ortaya çıkan eşitsizliğe bütçe açığı denir.

Alternatiflerin ve kriterlerin belirlenmesinin ardından karar matrisi Tablo 4’te görüldüğü gibi oluşturulmuştur. 2013 yılına ait verilerinden yararlanarak, 29 alternatif ve 6 kriterden oluşan 29x6 boyutlu standart karar matrisi oluşturulmuştur.

Karar matrisinin oluşturulmasının ardından Eşitlik (1) yardımıyla, normalize karar matrisi Tablo 5'te görüldügü gibi oluşturulmuştur.

Tablo 5. Normalize Karar Matrisi

\begin{tabular}{lcccccc}
\hline & \multicolumn{5}{c}{ Kriterler } \\
\hline Alternatifler & $\mathbf{K}_{\mathbf{1}}$ & $\mathbf{K}_{\mathbf{2}}$ & $\mathbf{K}_{\mathbf{3}}$ & $\mathbf{K}_{\mathbf{4}}$ & $\mathbf{K}_{\mathbf{5}}$ & $\mathbf{K}_{\mathbf{6}}$ \\
\hline Belçika & 0,224 & 0,104 & 0,127 & 0,181 & 0,233 & $-0,098$ \\
Bulgaristan & 0,035 & 0,035 & 0,196 & 0,176 & 0,043 & $-0,057$ \\
Çek Cum. & 0,094 & 0,122 & 0,106 & 0,192 & 0,106 & $-0,057$ \\
Danimarka & 0,283 & 0,043 & 0,106 & 0,199 & 0,102 & $-0,030$ \\
Almanya & 0,215 & 0,139 & 0,078 & 0,204 & 0,180 & 0,000 \\
Estonya & 0,089 & 0,278 & 0,130 & 0,181 & 0,023 & $-0,008$ \\
İlanda & 0,239 & 0,043 & 0,198 & 0,222 & 0,284 & $-0,273$ \\
Yunanistan & 0,104 & $-0,078$ & 0,415 & 0,162 & 0,403 & $-0,481$ \\
İspanya & 0,141 & 0,130 & 0,394 & 0,199 & 0,216 & $-0,269$ \\
Fransa & 0,202 & 0,087 & 0,155 & 0,169 & 0,215 & $-0,163$ \\
Hirvatistan & 0,064 & 0,200 & 0,261 & 0,180 & 0,154 & $-0,185$ \\
İtalya & 0,166 & 0,113 & 0,183 & 0,193 & 0,305 & $-0,114$ \\
Güney K. & 0,132 & 0,035 & 0,240 & 0,187 & 0,257 & $-0,204$ \\
Letonya & 0,073 & 0,000 & 0,180 & 0,169 & 0,088 & $-0,038$ \\
Litvanya & 0,074 & 0,104 & 0,178 & 0,180 & 0,091 & $-0,083$ \\
Lüksemburg & 0,522 & 0,148 & 0,089 & 0,215 & 0,053 & 0,004 \\
Macaristan & 0,064 & 0,148 & 0,154 & 0,194 & 0,182 & $-0,083$ \\
Malta & 0,112 & 0,087 & 0,097 & 0,184 & 0,168 & $-0,106$ \\
Hollanda & 0,241 & 0,226 & 0,110 & 0,203 & 0,169 & $-0,095$ \\
Avusturya & 0,239 & 0,183 & 0,081 & 0,190 & 0,171 & $-0,057$ \\
Polonya & 0,065 & 0,070 & 0,155 & 0,185 & 0,131 & $-0,163$ \\
Portekiz & 0,103 & 0,035 & 0,247 & 0,182 & 0,297 & $-0,185$ \\
Romanya & 0,045 & 0,278 & 0,107 & 0,175 & 0,088 & $-0,087$ \\
Slovenya & 0,110 & 0,165 & 0,152 & 0,193 & 0,165 & $-0,556$ \\
Slovakya & 0,085 & 0,130 & 0,214 & 0,187 & 0,127 & $-0,106$ \\
Finlandiya & 0,233 & 0,191 & 0,124 & 0,174 & 0,131 & $-0,079$ \\
İsveç & 0,286 & 0,035 & 0,121 & 0,201 & 0,093 & $-0,042$ \\
İngiltere & 0,198 & 0,226 & 0,115 & 0,167 & 0,208 & $-0,220$ \\
Türkiye & 0,042 & 0,652 & 0,136 & 0,107 & 0,083 & $-0,072$ \\
\hline & & & & & &
\end{tabular}


Normalize karar matrisinin oluşturulması aşamasına kadar olan adımlar TOPSIS ve MOORA yöntemlerinde aynıdır. Yapılacak hesaplamalar bu aşamadan sonra farklılık göstermektedir.

\section{TOPSIS Yöntemi ile Sıralama}

TOPSIS yönteminin adımlarına göre normalize karar matrisinin elde edilmesinden sonra, Eşitlik (3)'te görüldügü gibi her kriter için alternatiflerin değerlendirme sonuçları, ilgili kriterin ağırlığı ile çarpılarak ağırlıklı normalize karar matrisi Tablo 6'da görüldü- ğü gibi oluşturulmuştur. Alternatiflerin seçimi veya sıralanmasında, karar verici açısından kriterlerin karar üzerindeki ağırlığı farklı olabilir. Bu çalışmada kriterler arasında ağırlıklar açısından fark olmadığı düşünülerek ağırlıklar, 1/ kriter sayısı şeklinde elde edilmiştir.

$$
\begin{aligned}
& w_{1}=1 / 6=0.167, \quad w_{2}=0.167, \quad w_{3}=0.167, \\
& w_{4}=0.167, w_{5}=0.167, \quad w_{6}=0.167
\end{aligned}
$$

\begin{tabular}{|c|c|c|c|c|c|c|}
\hline \multirow[b]{2}{*}{ Alternatifler } & \multicolumn{6}{|c|}{ Kriterler } \\
\hline & $\mathbf{K}_{1}$ & $\mathbf{K}_{2}$ & $\mathbf{K}_{3}$ & $\mathbf{K}_{4}$ & $\mathbf{K}_{5}$ & $\mathrm{~K}_{6}$ \\
\hline Belçika & 0,037 & 0,017 & 0,021 & 0,030 & 0,039 & $-0,016$ \\
\hline Bulgaristan & 0,006 & 0,006 & 0,033 & 0,029 & 0,007 & $-0,009$ \\
\hline Çek Cum. & 0,016 & 0,020 & 0,018 & 0,032 & 0,018 & $-0,009$ \\
\hline Danimarka & 0,047 & 0,007 & 0,018 & 0,033 & 0,017 & $-0,005$ \\
\hline Almanya & 0,036 & 0,023 & 0,013 & 0,034 & 0,030 & 0,000 \\
\hline Estonya & 0,015 & 0,046 & 0,022 & 0,030 & 0,004 & $-0,001$ \\
\hline İrlanda & 0,040 & 0,007 & 0,033 & 0,037 & 0,047 & $-0,045$ \\
\hline Yunanistan & 0,017 & $-0,013$ & 0,069 & 0,027 & 0,067 & $-0,080$ \\
\hline İspanya & 0,024 & 0,022 & 0,066 & 0,033 & 0,036 & $-0,045$ \\
\hline Fransa & 0,034 & 0,014 & 0,026 & 0,028 & 0,036 & $-0,027$ \\
\hline Hurvatistan & 0,011 & 0,033 & 0,043 & 0,030 & 0,026 & $-0,031$ \\
\hline İtalya & 0,028 & 0,019 & 0,030 & 0,032 & 0,051 & $-0,019$ \\
\hline Güney K. & 0,022 & 0,006 & 0,040 & 0,031 & 0,043 & $-0,034$ \\
\hline Letonya & 0,012 & 0,000 & 0,030 & 0,028 & 0,015 & $-0,006$ \\
\hline Litvanya & 0,012 & 0,017 & 0,030 & 0,030 & 0,015 & $-0,014$ \\
\hline Lüksemburg & 0,087 & 0,025 & 0,015 & 0,036 & 0,009 & 0,001 \\
\hline Macaristan & 0,011 & 0,025 & 0,026 & 0,032 & 0,030 & $-0,014$ \\
\hline Malta & 0,019 & 0,014 & 0,016 & 0,031 & 0,028 & $-0,018$ \\
\hline Hollanda & 0,040 & 0,038 & 0,018 & 0,034 & 0,028 & $-0,016$ \\
\hline Avusturya & 0,040 & 0,030 & 0,014 & 0,032 & 0,029 & $-0,009$ \\
\hline Polonya & 0,011 & 0,012 & 0,026 & 0,031 & 0,022 & $-0,027$ \\
\hline Portekiz & 0,017 & 0,006 & 0,041 & 0,030 & 0,049 & $-0,031$ \\
\hline Romanya & 0,008 & 0,046 & 0,018 & 0,029 & 0,015 & $-0,015$ \\
\hline Slovenya & 0,018 & 0,028 & 0,025 & 0,032 & 0,027 & $-0,093$ \\
\hline Slovakya & 0,014 & 0,022 & 0,036 & 0,031 & 0,021 & $-0,018$ \\
\hline Finlandiya & 0,039 & 0,032 & 0,021 & 0,029 & 0,022 & $-0,013$ \\
\hline İsveç & 0,048 & 0,006 & 0,020 & 0,033 & 0,016 & $-0,007$ \\
\hline İngiltere & 0,033 & 0,038 & 0,019 & 0,028 & 0,035 & $-0,037$ \\
\hline Türkiye & 0,007 & 0,109 & 0,023 & 0,018 & 0,014 & $-0,012$ \\
\hline $\mathbf{w}_{\mathrm{j}}$ & 0,167 & 0,167 & 0,167 & 0,167 & 0,167 & 0,167 \\
\hline
\end{tabular}

Tablo 6. Ağırlıklandırılmış Normalize Karar Matrisi

Ağırlıklı normalize karar matrisinin oluşturulmasının ardından pozitif ideal $\left(A^{+}\right)$ve negatif ideal $\left(A^{-}\right)$ çözüm kümeleri belirlenmiştir. $A^{+}$kümesi için $V$ matrisinin her bir sütunundaki maksimize edilmesi gereken kriterler için en büyük değerler, minimize edilmesi gereken kriterler için en küçük değerler seçilmiş ve $A^{+}$kümesi aşağıdaki gibi oluşturulmuştur;
$A^{+}=\{0.087,-0.013,0.013,0.037,0.004,0.001\}$

$A^{-}$seti için $V$ matrisinin her bir sütunundaki maksimize edilmesi gereken kriterler için en küçük değerler, minimize edilmesi gereken kriterler için en büyük değerler seçilmiş ve kümesi aşağıdaki gibi oluşturulmuştur. 
$A^{-}=\{0.006 ; 0,109 ; 0,069 ; 0.018 ; 0,067,-0,093\}$

Pozitif ve negatif ideal çözümlerin belirlenmesinin ardından, her alternatifin pozitif ideal çözüme olan uzaklıkları Eşitlik (7) yardımıyla hesaplanmış ve Tablo 7'de hesaplama sonuçları verilmiştir.
Her alternatifin negatif ideal çözüme olan uzaklı̆̆g ise Eşitlik (8) yardımıyla hesaplanmıştır. Bu hesaplama sonuçları Tablo 8'de görülmektedir.

\begin{tabular}{cccccccc}
\multicolumn{7}{c}{ Tablo 7. Alternatiflerin Pozitif Ideal çözüme Olan Uzaklıları } \\
\hline$S_{1}^{+}$ & 0,071 & $S_{9}^{+}$ & 0,106 & $S_{17}^{+}$ & 0,091 & $S_{25}^{+}$ & 0,088 \\
$S_{2}^{+}$ & 0,087 & $S_{10}^{+}$ & 0,075 & $S_{18}^{+}$ & 0,080 & $S_{26}^{+}$ & 0,071 \\
$S_{3}^{+}$ & 0,081 & $S_{11}^{+}$ & 0,102 & $S_{19}^{+}$ & 0,075 & $S_{27}^{+}$ & 0,047 \\
$S_{4}^{+}$ & 0,047 & $S_{12}^{+}$ & 0,086 & $S_{20}^{+}$ & 0,070 & $S_{28}^{+}$ & 0,089 \\
$S_{5}^{+}$ & 0,068 & $S_{13}^{+}$ & 0,090 & $S_{21}^{+}$ & 0,088 & $S_{29}^{+}$ & 0,148 \\
$S_{6}^{+}$ & 0,094 & $S_{14}^{+}$ & 0,079 & $S_{22}^{+}$ & 0,096 & & \\
$S_{7}^{+}$ & 0,084 & $S_{15}^{+}$ & 0,085 & $S_{23}^{+}$ & 0,102 & & \\
$S_{8}^{+}$ & 0,137 & $S_{16}^{+}$ & 0,038 & $S_{24}^{+}$ & 0,126 & & \\
\hline
\end{tabular}

\section{Tablo 8. Alternatiflerin Negatifideal Çözüme Olan Uzaklıkları}

\begin{tabular}{|c|c|c|c|c|c|c|c|}
\hline$S_{1}^{-}$ & 0,136 & $S_{9}^{-}$ & 0,107 & $S_{17}^{-}$ & 0,129 & $S_{25}^{-}$ & 0,129 \\
\hline$S_{2}^{-}$ & 0,150 & $S_{10}^{-}$ & 0,130 & $S_{18}^{-}$ & 0,139 & $S_{26}^{-}$ & 0,134 \\
\hline$S_{3}^{-}$ & 0,142 & $S_{11}^{-}$ & 0,110 & $S_{19}^{-}$ & 0,128 & $S_{27}^{-}$ & 0,158 \\
\hline$S_{4}^{-}$ & 0,158 & $S_{12}^{-}$ & 0,126 & $S_{20}^{-}$ & 0,138 & $S_{28}^{-}$ & 0,112 \\
\hline$S_{5}^{-}$ & 0,147 & $S_{13}^{-}$ & 0,126 & $S_{21}^{-}$ & 0,134 & $S_{29}^{-}$ & 0,107 \\
\hline$S_{6}^{-}$ & 0,137 & $S_{14}^{-}$ & 0,154 & $S_{22}^{-}$ & 0,126 & & \\
\hline$S_{7}^{-}$ & 0,125 & $S_{15}^{-}$ & 0,138 & $S_{23}^{-}$ & 0,125 & & \\
\hline$S_{8}^{-}$ & 0,123 & $S_{16}^{-}$ & 0,170 & $S_{24}^{-}$ & 0,102 & & \\
\hline
\end{tabular}

Alternatiflerin pozitif ve negatif ideal çözümlere olan uzaklıklarının hesaplanmasından sonra ideal çözüme göreli yakınlıklar Eşitlik (9) yardımıyla Tablo 9'da görüldüğü gibi elde edilmiştir.
$C_{i}^{*}$ değerleri büyükten küçüğe doğru dizilerek alternatiflerin performans sıraları belirlenmiştir. Tablo 10 'da AB'ye üye olan 28 ülke ve aday ülke Türkiye için TOPSIS yöntemi ile elde edilen sıralama sonuçları görülmektedir. 


\section{Tablo 9. İdeal Çözüme Göreli Yakınlık Değerleri}

\begin{tabular}{llllllll}
\hline$C_{1}^{*}$ & 0,657 & $C_{9}^{*}$ & 0,503 & $C_{17}^{*}$ & 0,586 & $C_{25}^{*}$ & 0,596 \\
$C_{2}^{*}$ & 0,634 & $C_{10}^{*}$ & 0,634 & $C_{18}^{*}$ & 0,634 & $C_{26}^{*}$ & 0,654 \\
$C_{3}^{*}$ & 0,637 & $C_{11}^{*}$ & 0,518 & $C_{19}^{*}$ & 0,630 & $C_{27}^{*}$ & 0,773 \\
$C_{4}^{*}$ & 0,770 & $C_{12}^{*}$ & 0,594 & $C_{20}^{*}$ & 0,664 & $C_{28}^{*}$ & 0,557 \\
$C_{5}^{*}$ & 0,683 & $C_{13}^{*}$ & 0,584 & $C_{21}^{*}$ & 0,603 & $C_{29}^{*}$ & 0,420 \\
$C_{6}^{*}$ & 0,593 & $C_{14}^{*}$ & 0,660 & $C_{22}^{*}$ & 0,568 & & \\
$C_{7}^{*}$ & 0,599 & $C_{15}^{*}$ & 0,620 & $C_{23}^{*}$ & 0,551 & & \\
$C_{8}^{*}$ & 0,474 & $C_{16}^{*}$ & 0,817 & $C_{24}^{*}$ & 0,448 & & \\
\hline
\end{tabular}

Tablo 10. Alternatiflerin Sıralanması

\begin{tabular}{clclll}
\hline SIra & Alternatifler & $\mathrm{C}_{\mathrm{i}}^{*}$ & Sira & Alternatifler & $\mathrm{C}_{\mathrm{i}}^{*}$ \\
\hline $\mathbf{1}$ & Lüksemburg & 0,817 & $\mathbf{1 6}$ & İrlanda & 0,599 \\
$\mathbf{2}$ & İsveç & 0,773 & $\mathbf{1 7}$ & Slovakya & 0,596 \\
$\mathbf{3}$ & Danimarka & 0,770 & $\mathbf{1 8}$ & İtalya & 0,594 \\
$\mathbf{4}$ & Almanya & 0,683 & $\mathbf{1 9}$ & Estonya & 0,593 \\
$\mathbf{5}$ & Avusturya & 0,664 & $\mathbf{2 0}$ & Macaristan & 0,586 \\
$\mathbf{6}$ & Letonya & 0,660 & $\mathbf{2 1}$ & Güney K. & 0,584 \\
$\mathbf{7}$ & Belçika & 0,657 & $\mathbf{2 2}$ & Portekiz & 0,568 \\
$\mathbf{8}$ & Finlandiya & 0,654 & $\mathbf{2 3}$ & İngiltere & 0,557 \\
$\mathbf{9}$ & Çek Cum. & 0,637 & $\mathbf{2 4}$ & Romanya & 0,551 \\
$\mathbf{1 0}$ & Bulgaristan & 0,634 & $\mathbf{2 5}$ & Hirvatistan & 0,518 \\
$\mathbf{1 1}$ & Malta & 0,634 & $\mathbf{2 6}$ & İspanya & 0,503 \\
$\mathbf{1 2}$ & Fransa & 0,634 & $\mathbf{2 7}$ & Yunanistan & 0,474 \\
$\mathbf{1 3}$ & Hollanda & 0,630 & $\mathbf{2 8}$ & Slovenya & 0,448 \\
$\mathbf{1 4}$ & Litvanya & 0,620 & $\mathbf{2 9}$ & Türkiye & 0,420 \\
$\mathbf{1 5}$ & Polonya & 0,603 & & & \\
\hline
\end{tabular}

\section{MOORA Yöntemi ile Sıralama}

MOORA-Oran yöntemine göre normalize karar matrisinin elde edilmesinden sonra, kriterler maksimum veya minimum olmalarına göre belirlenerek, maksimum kriterlere ait toplam değer ve minimum kriterlere ait toplam değer ayrı ayrı hesaplanmış ve
Eşitlik (10) yardımıyla elde edilen bu değerlerin farkı alınarak her bir alternatif için tek bir değere $\left(y_{i}^{*}\right)$ ulaşılmıştır. Elde edilen bu değerler Tablo 11'de görülmektedir. 
Tablo 11. Alternatiflerin $y_{i}^{*}$ değerleri

\begin{tabular}{|c|c|c|c|c|c|c|c|}
\hline & Maks & Min & Min & Maks & Min & Maks & \\
\hline Alternatifler & $\mathbf{K}_{1}$ & $\mathbf{K}_{2}$ & $\overline{K_{3}}$ & $\mathbf{K}_{4}$ & $K_{5}$ & $\overline{K_{6}}$ & $y_{i}^{*}$ \\
\hline Belçika & 0,224 & 0,104 & 0,127 & 0,181 & 0,233 & $-0,098$ & $-0,159$ \\
\hline Bulgaristan & 0,035 & 0,035 & 0,196 & 0,176 & 0,043 & $-0,057$ & $-0,120$ \\
\hline Çek Cum. & 0,094 & 0,122 & 0,106 & 0,192 & 0,106 & $-0,057$ & $-0,103$ \\
\hline Danimarka & 0,283 & 0,043 & 0,106 & 0,199 & 0,102 & $-0,030$ & 0,200 \\
\hline Almanya & 0,215 & 0,139 & 0,078 & 0,204 & 0,180 & 0,000 & 0,021 \\
\hline Estonya & 0,089 & 0,278 & 0,130 & 0,181 & 0,023 & $-0,008$ & $-0,168$ \\
\hline İrlanda & 0,239 & 0,043 & 0,198 & 0,222 & 0,284 & $-0,273$ & $-0,338$ \\
\hline Yunanistan & 0,104 & $-0,078$ & 0,415 & 0,162 & 0,403 & $-0,481$ & $-0,954$ \\
\hline İspanya & 0,141 & 0,130 & 0,394 & 0,199 & 0,216 & $-0,269$ & $-0,668$ \\
\hline Fransa & 0,202 & 0,087 & 0,155 & 0,169 & 0,215 & $-0,163$ & $-0,250$ \\
\hline Hirvatistan & 0,064 & 0,200 & 0,261 & 0,180 & 0,154 & $-0,185$ & $-0,557$ \\
\hline İtalya & 0,166 & 0,113 & 0,183 & 0,193 & 0,305 & $-0,114$ & $-0,354$ \\
\hline Güney K. & 0,132 & 0,035 & 0,240 & 0,187 & 0,257 & $-0,204$ & $-0,417$ \\
\hline Letonya & 0,073 & 0,000 & 0,180 & 0,169 & 0,088 & $-0,038$ & $-0,063$ \\
\hline Litvanya & 0,074 & 0,104 & 0,178 & 0,180 & 0,091 & $-0,083$ & $-0,202$ \\
\hline Lüksemburg & 0,522 & 0,148 & 0,089 & 0,215 & 0,053 & 0,004 & 0,451 \\
\hline Macaristan & 0,064 & 0,148 & 0,154 & 0,194 & 0,182 & $-0,083$ & $-0,309$ \\
\hline Malta & 0,112 & 0,087 & 0,097 & 0,184 & 0,168 & $-0,106$ & $-0,161$ \\
\hline Hollanda & 0,241 & 0,226 & 0,110 & 0,203 & 0,169 & $-0,095$ & $-0,156$ \\
\hline Avusturya & 0,239 & 0,183 & 0,081 & 0,190 & 0,171 & $-0,057$ & $-0,062$ \\
\hline Polonya & 0,065 & 0,070 & 0,155 & 0,185 & 0,131 & $-0,163$ & $-0,269$ \\
\hline Portekiz & 0,103 & 0,035 & 0,247 & 0,182 & 0,297 & $-0,185$ & $-0,479$ \\
\hline Romanya & 0,045 & 0,278 & 0,107 & 0,175 & 0,088 & $-0,087$ & $-0,341$ \\
\hline Slovenya & 0,110 & 0,165 & 0,152 & 0,193 & 0,165 & $-0,556$ & $-0,736$ \\
\hline Slovakya & 0,085 & 0,130 & 0,214 & 0,187 & 0,127 & $-0,106$ & $-0,306$ \\
\hline Finlandiya & 0,233 & 0,191 & 0,124 & 0,174 & 0,131 & $-0,079$ & $-0,119$ \\
\hline İsveç & 0,286 & 0,035 & 0,121 & 0,201 & 0,093 & $-0,042$ & 0,196 \\
\hline İngiltere & 0,198 & 0,226 & 0,115 & 0,167 & 0,208 & $-0,220$ & $-0,404$ \\
\hline Türkiye & 0,042 & 0,652 & 0,136 & 0,107 & 0,083 & $-0,072$ & $-0,794$ \\
\hline
\end{tabular}

Alternatiflere ilişkin $y_{i}^{*}$ değerleri hesaplandıktan sonra, büyükten küçüğe sıralanarak ülkeler arasında- ki performans sıralamasına ulașılmıștır. Elde edilen bu sonuçlar Tablo 12'de görülmektedir. 
Tablo 12. MO0RA-Oran Yöntemine Göre Sıralama

\begin{tabular}{clcllc}
\hline Sıra & Alternatifler & $y_{i}^{*}$ & Sıra & Alternatifler & $y_{i}^{*}$ \\
\hline $\mathbf{1}$ & Lüksemburg & 0,451 & $\mathbf{1 6}$ & Polonya & $-0,269$ \\
$\mathbf{2}$ & Danimarka & 0,200 & $\mathbf{1 7}$ & Slovakya & $-0,306$ \\
$\mathbf{3}$ & İsveç & 0,196 & $\mathbf{1 8}$ & Macaristan & $-0,309$ \\
$\mathbf{4}$ & Almanya & 0,021 & $\mathbf{1 9}$ & İrlanda & $-0,338$ \\
$\mathbf{5}$ & Avusturya & $-0,062$ & $\mathbf{2 0}$ & Romanya & $-0,341$ \\
$\mathbf{6}$ & Letonya & $-0,063$ & $\mathbf{2 1}$ & İtalya & $-0,354$ \\
$\mathbf{7}$ & Çek Cum. & $-0,103$ & $\mathbf{2 2}$ & İngiltere & $-0,404$ \\
$\mathbf{8}$ & Finlandiya & $-0,119$ & $\mathbf{2 3}$ & Güney K. & $-0,417$ \\
$\mathbf{9}$ & Bulgaristan & $-0,120$ & $\mathbf{2 4}$ & Portekiz & $-0,479$ \\
$\mathbf{1 0}$ & Hollanda & $-0,156$ & $\mathbf{2 5}$ & Hirvatistan & $-0,557$ \\
$\mathbf{1 1}$ & Belçika & $-0,159$ & $\mathbf{2 6}$ & İspanya & $-0,668$ \\
$\mathbf{1 2}$ & Malta & $-0,161$ & $\mathbf{2 7}$ & Slovenya & $-0,736$ \\
$\mathbf{1 3}$ & Estonya & $-0,168$ & $\mathbf{2 8}$ & Türkiye & $-0,794$ \\
$\mathbf{1 4}$ & Litvanya & $-0,202$ & $\mathbf{2 9}$ & Yunanistan & $-0,954$ \\
$\mathbf{1 5}$ & Fransa & $-0,250$ & & & \\
\hline
\end{tabular}

MOORA- Referans Nokta yöntemine göre normalize karar matrisinin elde edilmesinden sonra, her kriter için referans noktalar ( $r_{j}^{\prime}$ ler) belirlenmiştir. Referans noktalar belirlenirken, amaç maksimizasyon ise mak- simum noktalar, amaç minimizasyon ise minimum noktalar alınır. Her bir kriter için belirlenen referans noktalar şu şekilde verilebilir:

$$
r_{j}=\{0,522, \quad-0,078, \quad 0,078, \quad 0,222, \quad 0,023, \quad 0,004\}
$$

Belirlenen bu noktaların her $x_{j}^{*}$ ile olan uzaklıkları Eşitlik (11) yardımıyla hesaplanmış ve Tablo 13'te verilmiştir. Oluşturulan yeni matrise Eşitlik (12) uygu- lanarak sıralamaya ulaşılmıştır. MOORA- Referans Nokta yöntemine göre elde edilen sıralama sonuçları Tablo 14'te görülmektedir. 
Tablo 13. MOORA-Referans Nokta Yöntemi

\begin{tabular}{|c|c|c|c|c|c|c|c|}
\hline & Maks & Min & Min & Maks & Min & Maks & \\
\hline Alternatifler & $\mathbf{K}_{1}$ & $\mathbf{K}_{2}$ & $\mathbf{K}_{3}$ & $\mathbf{K}_{4}$ & $\mathbf{K}_{5}$ & $\mathbf{K}_{6}$ & Maks \\
\hline Belçika & 0,298 & 0,183 & 0,048 & 0,041 & 0,210 & 0,102 & 0,298 \\
\hline Bulgaristan & 0,487 & 0,113 & 0,118 & 0,045 & 0,020 & 0,061 & 0,487 \\
\hline Çek Cum. & 0,428 & 0,200 & 0,027 & 0,029 & 0,083 & 0,061 & 0,428 \\
\hline Danimarka & 0,239 & 0,122 & 0,027 & 0,023 & 0,079 & 0,034 & 0,239 \\
\hline Almanya & 0,307 & 0,217 & 0,000 & 0,018 & 0,157 & 0,004 & 0,307 \\
\hline Estonya & 0,433 & 0,356 & 0,051 & 0,041 & 0,000 & 0,011 & 0,433 \\
\hline İrlanda & 0,283 & 0,122 & 0,119 & 0,000 & 0,261 & 0,276 & 0,283 \\
\hline Yunanistan & 0,418 & 0,000 & 0,336 & 0,060 & 0,380 & 0,485 & 0,485 \\
\hline İspanya & 0,381 & 0,209 & 0,315 & 0,022 & 0,193 & 0,273 & 0,381 \\
\hline Fransa & 0,320 & 0,165 & 0,077 & 0,053 & 0,192 & 0,167 & 0,320 \\
\hline Hirvatistan & 0,458 & 0,278 & 0,183 & 0,042 & 0,131 & 0,189 & 0,458 \\
\hline İtalya & 0,355 & 0,191 & 0,104 & 0,028 & 0,282 & 0,117 & 0,355 \\
\hline Güney K. & 0,390 & 0,113 & 0,161 & 0,035 & 0,234 & 0,208 & 0,390 \\
\hline Letonya & 0,449 & 0,078 & 0,101 & 0,052 & 0,065 & 0,042 & 0,449 \\
\hline Litvanya & 0,448 & 0,183 & 0,100 & 0,041 & 0,068 & 0,087 & 0,448 \\
\hline Lüksemburg & 0,000 & 0,226 & 0,011 & 0,007 & 0,030 & 0,000 & 0,226 \\
\hline Macaristan & 0,458 & 0,226 & 0,075 & 0,027 & 0,159 & 0,087 & 0,458 \\
\hline Malta & 0,409 & 0,165 & 0,018 & 0,037 & 0,145 & 0,110 & 0,409 \\
\hline Hollanda & 0,281 & 0,304 & 0,032 & 0,018 & 0,146 & 0,098 & 0,304 \\
\hline Avusturya & 0,283 & 0,261 & 0,003 & 0,031 & 0,148 & 0,061 & 0,283 \\
\hline Polonya & 0,457 & 0,148 & 0,077 & 0,036 & 0,108 & 0,167 & 0,457 \\
\hline Portekiz & 0,419 & 0,113 & 0,169 & 0,039 & 0,274 & 0,189 & 0,419 \\
\hline Romanya & 0,477 & 0,356 & 0,029 & 0,047 & 0,065 & 0,091 & 0,477 \\
\hline Slovenya & 0,412 & 0,243 & 0,074 & 0,028 & 0,142 & 0,560 & 0,560 \\
\hline Slovakya & 0,436 & 0,209 & 0,136 & 0,035 & 0,104 & 0,110 & 0,436 \\
\hline Finlandiya & 0,289 & 0,269 & 0,045 & 0,048 & 0,108 & 0,083 & 0,289 \\
\hline İsveç & 0,236 & 0,113 & 0,042 & 0,021 & 0,070 & 0,045 & 0,236 \\
\hline İngiltere & 0,324 & 0,304 & 0,036 & 0,055 & 0,185 & 0,223 & 0,324 \\
\hline Türkiye & 0,480 & 0,730 & 0,057 & 0,114 & 0,060 & 0,076 & 0,730 \\
\hline
\end{tabular}

Tablo 14. M00RA-Referans Nokta Yöntemine Göre Sıralama

\begin{tabular}{clcclc}
\hline Sira & Alternatifler & $y_{i}^{*}$ & Sira & Alternatifler & $y_{i}^{*}$ \\
\hline $\mathbf{1}$ & Lüksemburg & 0,226 & $\mathbf{1 6}$ & Portekiz & 0,419 \\
$\mathbf{2}$ & İsveç & 0,236 & $\mathbf{1 7}$ & Çek Cum. & 0,428 \\
$\mathbf{3}$ & Danimarka & 0,239 & $\mathbf{1 8}$ & Estonya & 0,433 \\
$\mathbf{4}$ & Avusturya & 0,282 & $\mathbf{1 9}$ & Slovakya & 0,436 \\
$\mathbf{5}$ & İrlanda & 0,283 & $\mathbf{2 0}$ & Litvanya & 0,448 \\
$\mathbf{6}$ & Finlandiya & 0,289 & $\mathbf{2 1}$ & Letonya & 0,449 \\
$\mathbf{7}$ & Belçika & 0,298 & $\mathbf{2 2}$ & Polonya & 0,457 \\
$\mathbf{8}$ & Hollanda & 0,304 & $\mathbf{2 3}$ & Hirvatistan & 0,458 \\
$\mathbf{9}$ & Almanya & 0,307 & $\mathbf{2 4}$ & Macaristan & 0,458 \\
$\mathbf{1 0}$ & Fransa & 0,320 & $\mathbf{2 5}$ & Romanya & 0,477 \\
$\mathbf{1 1}$ & İngiltere & 0,324 & $\mathbf{2 6}$ & Yunanistan & 0,485 \\
$\mathbf{1 2}$ & İtalya & 0,355 & $\mathbf{2 7}$ & Bulgaristan & 0,487 \\
$\mathbf{1 3}$ & İspanya & 0,381 & $\mathbf{2 8}$ & Slovenya & 0,560 \\
$\mathbf{1 4}$ & Güney K. & 0,390 & $\mathbf{2 9}$ & Türkiye & 0,730 \\
$\mathbf{1 5}$ & Malta & 0,409 & & & \\
\hline
\end{tabular}




\section{Bulgular}

TOPSIS ve MOORA-Oran, MOORA Referans Nokta yöntemleri ile elde edilen $\mathrm{AB}$ ülkeleri ve aday ülke Türkiye arasındaki sıralama sonuçları karşılaştırmalı olarak Tablo 15’te verilmiştir. Aynı veriler kullanılmasına rağmen her bir yöntem ile farklı sıralama elde edilmesinin nedeni, yöntemlerin sıralama yaparken dikkate aldıkları yaklaşımların farklı olmasıdır.

Tablo 15. TOPSIS ve MOORA Yöntemlerine Göre Sıralama Sonuçları

\begin{tabular}{lccc}
\hline Alternatifler & TOPSIS & MOORA-Oran & $\begin{array}{c}\text { MOORA- } \\
\text { Referans Nokta }\end{array}$ \\
\hline Belçika & 7 & 11 & 7 \\
Bulgaristan & 10 & 9 & 27 \\
Çek Cum. & 9 & 7 & 17 \\
Danimarka & 3 & 2 & 3 \\
Almanya & 4 & 4 & 9 \\
Estonya & 19 & 13 & 18 \\
İrlanda & 16 & 19 & 5 \\
Yunanistan & 27 & 29 & 26 \\
İspanya & 26 & 26 & 13 \\
Fransa & 12 & 15 & 10 \\
Hirvatistan & 25 & 25 & 23 \\
İtalya & 18 & 21 & 12 \\
Güney K. & 21 & 23 & 14 \\
Letonya & 6 & 6 & 21 \\
Litvanya & 14 & 14 & 20 \\
Lüksemburg & 1 & 1 & 1 \\
Macaristan & 20 & 18 & 24 \\
Malta & 11 & 12 & 15 \\
Hollanda & 13 & 10 & 8 \\
Avusturya & 5 & 5 & 4 \\
Polonya & 15 & 16 & 22 \\
Portekiz & 22 & 24 & 16 \\
Romanya & 24 & 20 & 25 \\
Slovenya & 28 & 27 & 28 \\
Slovakya & 17 & 17 & 19 \\
Finlandiya & 8 & 8 & 29 \\
İsveç & 2 & 3 & \\
İngiltere & 23 & 28 & 28 \\
Türkiye & 29 & & 29 \\
\hline & & 29 & 2 \\
\hline
\end{tabular}

TOPSIS ve MOORA yöntemleri sonucunda elde edilen bu siralamaların birbirleri ile ne derece benzer olduklarının belirlenebilmesi için korelasyonları incelenmiştir. Elde edilen sonuçlara göre TOPSIS ve MOORA-Oran yöntemleri ile elde edilen siralama sonuçlarının sıra korelasyonu 0.97 iken, TOPSIS ve MOORA-Referans nokta yöntemleri ile elde edilen sıralama sonuçlarının sıra korelasyonu 0,67 olarak bulunmuştur. Elde edilen sonuçlara göre sıralama değerlerinin benzerlik gösterdiği söylenebilir. 
Tablo 16. TOPSIS ve MOORA Yöntemlerine Göre En İyi ve En Kötü 5 Alternatif

\begin{tabular}{llll}
\hline & TOPSIS & MOORA-Oran & MOORA-Referans Nokta \\
\hline 1 & Lüksemburg & Lüksemburg & Lüksemburg \\
2 & İsveç & Danimarka & İsveç \\
3 & Danimarka & İsveç & Danimarka \\
4 & Almanya & Almanya & Avusturya \\
5 & Avusturya & Avusturya & İrlanda \\
\hline 25 & Hırvatistan & Hırvatistan & Romanya \\
26 & İspanya & İspanya & Yunanistan \\
27 & Yunanistan & Slovenya & Bulgaristan \\
28 & Slovenya & Türkiye & Slovenya \\
29 & Türkiye & Yunanistan & Türkiye \\
\hline
\end{tabular}

Tablo 16'da ise TOPSIS ve MOORA yöntemlerine göre en iyi ve en kötü 5 alternatife yer verilmiștir. TOPSIS, MOORA-oran ve MOORA-referans nokta yöntemlerinin uygulanması sonucu alternatiflerin sıralamaların birbirlerine yakın olduğu görülmektedir. TOPSIS yöntemiyle yapılan sıralamada, birinci sırada Lüksemburg $(0,817)$, ikinci sırada İsveç $(0,773)$, üçüncü sırada Danimarka $(0,770)$, dördüncü sırada Almanya $(0,683)$ ve beşinci sırada Avusturya $(0,664)$ 'nın yer aldığ yönteminde ise ilk sirada Lüksemburg $(0,451)$, ikinci sırada Danimarka $(0,200)$, üçüncü sırada İsveç $(0,196)$, dördüncü sırada Almanya $(0,021)$ ve beşinci sırada ise Avusturya $\quad(-0,062)$ yer almaktadır. MOORA-referans nokta yönteminde ise sıralamalar, birinci sırada Lüksemburg $(0,226)$, ikinci sırada İsveç $(0,236)$, üçüncü sırada Danimarka $(0,239)$, dördüncü sırada Avusturya $(0,282)$ ve beşinci sırada İrlanda’nın $(0,283)$ yer aldığı görülmektedir.

TOPSIS yönteminde sıralamaların sonlarına doğru gelindiğinde, $25^{\prime}$ inci sırada Hırvatistan $(0,518), 26$ 'nci sirada İspanya $(0,503)$, 27 'nci sirada Yunanistan $(0,474), 28^{\prime}$ inci sirada Slovenya $(0,448)$ ve $29^{\prime}$ uncu sırada ise Türkiye $(0,420)$ yer almaktadır. MOORA-oran yöntemine göre, 25 'inci sırada Hırvatistan $(-0,557), 26{ }^{\prime}$ inc1 sirada İspanya $(-0,668), 27$ 'inci sirada Slovenya $(-0,736), 28$ 'inci sırada Türkiye $(-0,794)$ ve 29 'uncu sırada ise Yunanistan $(-0,954)$ yer almaktadır. MOORA-referans nokta yöntemine göre ise son siralamalarda, 25'inci sirada Romanya $(0,447)$, 26 'nci sirada Yunanistan $(0,485), 27$ 'inci surada Bulgaristan $(0,487), 28$ 'inci sirada Slovenya $(0,560)$ ve 29 'uncu sırada ise Türkiye $(0,730)$ yer almıștır.
Kişi başı milli gelir kriterine göre ülkelerin performanslarına bakıldığında (Tablo 6), 27'inci s1rada yer alan Romanyảnın 0.008 , 28 'inci siradaki Türkiye'nin 0.007 iken en düşük performans ise 0,006 ile Bulgaristan’a aittir. Kişi başına mili gelire göre en yüksek performansa sahip olan ülke ise 0,087 ile Lüksemburg'tur. İkinci sırada yer alan İsveç'in performansi 0.048'dir. 2012 yllında $A B$ ekonomik krizde olmasına rağmen Bulgaristan ekonomisi fazla etkilenmemiş ama önemli bir artışta kaydetmemiştir. Lüksemburg günümüzde, dünyanın New York’tan sonra ikinci büyük yatırım fonu merkezi, Euro bölgesinin de birinci özel bankacılık pazarıdır. Lüksemburg ekonomisinin lokomotifi olan finans sektörünün GSYİH>ya katkısı \%23,5`ni, sektör istihdamın \%11,27 >sini oluşturmaktadır (http://www.mfa.gov.tr/ luksemburg-ekonomisi.tr.mfa). Tablo 16'da görüldüğü gibi Lüksemburg her üç yöntem için de birinci sırayı almaktadır.

Negatif etkiye sahip olan enflasyon kriterine göre en düşük performansa sahip olan ülke Türkiye $(0,109)$ iken; en yüksek performansa sahip olan ülke ise Yunanistan $(-0,013)$ 'dır. Ayrica Tablo 4'te Avrupa Birliği’nde en yüksek enflasyon oranının 7,5 ile Türkiye 'de, en düşük enflasyon oran 1-0,9 ile Yunanistan'da olduğu görülmektedir. Yunanistan $\mathrm{AB}$ içindeki en borçlu ülke olmakla beraber, yapısal reformlar gerçekleştirmemiş olması krizden çıkmasını zorlaştırmaktadır (http://www.mfa.gov.tr/yunanistan-ekonomisi.tr.mfa). Birinci sırada yer alan Lüksemburg'un enflasyon kriterine göre performansı 0,025’tir. 
Negatif etkiye sahip olan işsizlik oranını kriterine göre en kötü performanslara sahip olan ülkeler Hirvatistan $(0,043)$, İspanya $(0,066)$ ve Yunanistan $(0.069)$ 'dır. Yunanistan $(27,5)$ ve İspanya $(26,1)$ şu anda Avrupa'da işsizlik oranın en yüksek olduğu ülkelerdir. İşsizlik kriterine göre performansı en iyi olan ülke ise $(0,013)$ ile Almanya'dır. Almanya'dan sonra en düşük işsizlik oranına sahip ülkeler Avusturya $(5,4)$ ve Lüksemburg $(5,9)$ 'dur. Türkiye'nin İşsizlik oranı kriterine göre performans1 $(0,023)$ olarak gerçekleşmiştir.

İhracatın ithalatı karşılama oranına bakıldığında ise en düşük performansa sahip olan ülke Türkiye $(0,018)$ iken, en iyi performansa sahip olan ülke ise İrlanda $(0,037)$ 'dır. Performansı yüksek olan İrlanda’nın, ihracatın ithalatı karşılama oranı diğer ülkelere göre daha iyidir. Birinci sırada yer alan Lüksemburg'un ihracatın ithalatı karşılama oranının performansı 0,036'dir.

Negatif etkiye sahip olan Kamu Borçları/GSYİH'ya bakıldığında 0.067 ile en düşük performansa sahip olan ülke Yunanistan'dır. En yüksek performansa sahip ülke ise 0.004 ile Estonya'dır. Lüksemburg'un performansı 0.009 iken, Türkiyennin performansı 0,014 olarak gerçekleşmiştir.

Negatif etkiye sahip olan Bütçe Açığı/GSYİH'ya bakıldığında en düşük performansa sahip olan ülkeler Slovenya $(-0,093)$, Yunanistan $(-0,080)$ ve İspanya $(-0,045)$ iken; en yüksek performansa sahip olan ülkeler ise Lüksemburg $(0,001)$, Almanya $(0,0)$ ve Estonya $(-0,001)$ olarak belirlenmiştir. Bütçe Açı̆̆g/ GSYİH oranı, -12,7 olan İspanyảnın diğer ülkelere göre daha fazla bütçe açığı vardır. Bütçe Açığı/GSYİH oranı 0,1 olan Lüksemburg'un ise bütçe açığı en azdır. Türkiye’nin Bütçe Açığı/GSYİH değeri ise -1,9'dur.

\section{Sonuç}

$\mathrm{Bu}$ çalışmanın amacı, ekonomik göstergelerle AB'ye üye olan ülkelerin ve aday ülke Türkiye’nin performans derecelerine göre sıralama yaparak, Türkiye'nin AB'ye üye olan ülkeler arasındaki ekonomik yerini göstermektir. TOPSIS, MOORA-oran ve MOORAreferans nokta yöntemleri kullanılarak, 2013 yılının makroekonomik verilerinden 6 kriter belirlenerek, ülkelerin ekonomik performansları değerlendirilmiş ve ülkeler arasındaki sıralama belirlenmiştir. TOPSIS ve MOORA-referans nokta yöntemleri sonucunda ekonomik performansları en yüksek olan ülkeler sıra- sıyla Lüksemburg, İsveç ve Danimarka'dır. Sıralamalarda sonlara doğru gelindiğinde, TOPSIS yöntemi sonucunda ekonomik performansı en düşük olan ülkeler sırasiyla Yunanistan, Slovenya ve Türkiye iken, MOORA-referans nokta yönteminde ise Bulgaristan, Slovenya ve Türkiye sonucuna ulaşılmıştır. MOORAoran yöntemi sonucunda ekonomik performansları en yüksek olan ülkeler sırasıyla Lüksemburg, Danimarka ve İsveç iken, ekonomik performansı en kötü olan ülkeler ise Slovenya, Türkiye ve Yunanistan'dır.

Çalı̧smada dikkate alınan kriterler performans sıralamalarını değiştirebilmektedir. Bu çalışmada, ilk üç sıra da yer alan Lüksemburg, İsveç, Danimarka gibi ülkelerin karar matrisinde kişi başına milli gelirlerin yüksek, işsizlik oranın düşük, ihracatın ithalatı karşlama oranın yüksek, enflasyon oranlarının düşük, bütçe açığı/GSYİH'ya oranının düşük, Kamu Borçları/GSYİH'ya oranının düşük olması, AB'ye üye olan ülkeler ve Türkiye’nin arasında ilk sıralarda yer almalarını sağlamıştır. Buradan da anlaşıldığı gibi bazı kriterler pozitif etki ya da negatif etki olarak yansimaktadır. AB üyesi ülkeler ve aday ülke Türkiye'nin bulunduğu ülkeler içinde en düşük performanslara sahip olan ülkeler ise Romanya, İspanya, Hirvatistan, Bulgaristan, Slovenya, Yunanistan ve Türkiye'dir. En düşük performansa sahip olan ülkeler; kişi başına düşen milli gelirleri düşük, işsizlik oranlarının yüksek, ihracatın ithalatı karşılama oranının düşük, Bütçe Açı̆̆ı/GSYİH'ya oranının yüksek, Kamu Borçları/ GSYİH'ya oranının yüksek olması sonucu son sıralarda yer almaktadırlar.

Ülkeler arasında sıralama yapılırken dikkate alınan kriterler değiştirildiğinde ve bu kriterlere farklı ağırlıklar atandığında sıralama sonuçları değişmektedir. Bu çalışmada görüldüğü gibi TOPSIS, MOORA-Oran ve MOORA-Referans Nokta yöntemleriyle basit matematiksel hesaplamalar ile siralama yapilabilmektedir. Değişen ekonomik koşullar nedeniyle düzenli olarak yapılacak bu tür çalışmalar, karar vericilere ülkelerinin konumları konusunda fikir vererek gerekli önlemleri almaları için yol gösterici olabilecektir.

Bundan sonraki çalışmalarda farklı ÇKKV yöntemleri ile de ülkeler arasındaki sıralamalar elde edilerek karşılaştırmalı analizler sunulabilir. Ayrıca bu çalışmada önerilen yöntemler ile Avrasya Ekonomi Topluluğu, Arap Birliği gibi farklı topluluklara üye ülkelerin performanslarına göre sıralamaları da elde edilebilir. 


\section{Kaynakça}

Akçay, B. (2008). Avrupa Birliği’nin Ekonomik Kriterleri ve Türkiye. Maliye Dergisi, 155, 11-38.

Alptekin N. (2015). Ranking of EU Countries and Turkey in Terms of Sustainable Development Indicators: An Integrated Approach Using Entropy And TOPSIS Methods, The 9th International Days of Statistics and Economics, Prague, September 1012.

Archana, M. and Sujatha, V. (2012). Application of Fuzzy MOORA and GRA in Multi Criterion Decision Making Problems", International Journal of Computer Applications, 53(9), 46-50.

Balezantis, A., Balezantis, T., Brauers, W.K.M. (2012). Multimoora-FG: A Multi-Objective Decision Making Method for Linguistic Reasoning with an Application to Personnel Selection. Informatica, 23(2), 173-190.

Baležentis, A. Baležentis, T., Valkauskas, R. (2010). Evaluating situation of Lithuania in the European Union: Structural indicators and MULTIMOORA method, Ukio Technologinis ir Ekonominis Vystymas, 16:4, 578-602.

Ballı, S. (2005). Fuzzy Çok Kriterli Karar Verme ve Basketbolda Oyuncu Seçimine Uygulanması (Yayımlanmamış Yüksek Lisans Tezi). Muğla Üniversitesi/ Fen Bilimleri Enstitüsü, Muğla.

Brauers, W.K.M., Ginevicius, R. (2009). Robustness in Regional Development Studies: The Case of Lithuania. Journal of Business Economics and Management, 10(2), 121-140.

Brauers, W.K.M., Ginevicius, R., Podvezko, V. (2010). Regional Development in Lithuania Considering Multiple Objectives by The MOORA Method. Technological and Economic Development of Economy, 16(4), 613-640.

Brauers, W.K.M., Zavadskas, E.K. (2006). The MOORA Method and Its Application to Privatization in a Transition Economy. Control and Cybernetics, 35(2), 445-469.
Brauers, W.K.M., Zavadskas, E.K. (2010). Project Management by Multimoora as an Instrument for Transition Economies. Technological and Economic Development of Economy, 16(1), 5-24.

Brauers, W.K.M., Zavadskas, E.K., Peldschus, F., Turskis, Z. (2008). Multi-Objective Decision Making for Road Design, Transport, 23(3), 183-193.

Brauers, W.K.M., Zavadskas, E.K., Turskis, Z. Vilutiene, T. (2008). Multi-Objective Contractor's Ranking by Applying the MOORA Method. Journal of Business Economics and Management, 9(4), 245255.

Chang J. R., Chen D. H., Hung C. T. (2005). Selecting Preventive Maintenance Treatments in Texas Using theTechnique for Order Preference by Similarity to the Ideal Solution for Specific Pavement Study-3 Sites. Journal of the Transportation Research Board, 1933, 62-71.

Çakır, S., Perçin, S. (2013). AB Ülkeleri’nde Bütünleşik Entropi Ağırlık-TOPSIS Yöntemiyle Ar-Ge Performansinın Ölçülmesi. Uludă̆ Üniversitesi İktisadi ve İdari Bilimler Fakültesi Dergisi, 32 (1), 77-95.

Dey, B., Bairagi, B., Sarkar, B. ve Sanyal, S. (2012). A Moora Based Fuzzy Multi Criteria Decision Making Approach for Supply Chain Strategy Selection. International Journal of Industrial Engineering Computations, 3, 649-662.

Esen, B. (2012). Avrupa Birliğine Üye Ülkeler İle Türkiye'nin Ekonomik Özelliklerinin İstatistiksel Yöntemlerle İncelenmesi. (Yayımlanmamış yüksek lisans tezi). Çukurova Üniversitesi/ Sosyal Bilimler Enstitüsü, Adana.

Gadakh, V. S. (2011). Application of MOORA Method for Parametric Optimization of Milling Process. International Journal of Applied Engineering Research, 1 (4), 743-758.

Genç, T., Masca, M. (2013). TOPSIS ve PROMETHEE Yöntemleri ile Elde Edilen Üstünlük Sıralamalarının Bir Uygulama Üzerinden Karşılaştırılması. Afyon Kocatepe Üniversitesi, İIBF Dergisi, 15(2), 539-567. 
Görener, A., Dinçer, H., Hacioğlu, Ü. (2013). Application of Multi-Objective Optimization on the Basis of Ratio Analysis (MOORA) Method for Bank Branch Location Selection. International Journal of Finance \& Banking Studies, 2(2), 41-52.

Günay A., Özen A. (2002). Avrupa Birliği'nde Mali Disiplinin Sağlanmasına Yönelik Maastricht Kriterlerinin Anayasal İktisat Perspektifinden Değerlendirilmesi. Dokuz Eylül Üniversitesi Sosyal Bilimler Enstitüsü Dergisi, 4(2), 66-82.

Gürbüz T., Albayrak Y. E. (2006). İnsan Kaynaklarında Bilgi Yönetimi Uygulaması Seçimi için Bulanık TOPSIS Kullanımı. Yöneylem Araştırması ve Endüstri Mühendisliği XXVI. Ulusal Kongresi Bildiriler Kitab1, Kocaeli, 426-428.

Hwang C. L., Yoon K., (1981). Multiple Attribute Decision Making Methods and Applications, Springer: Berlin Heidelberg.

İnan, A. (2005). Avrupa Birliği Ekonomik Yaklaşımı: Lizbon Stratejisi ve Maastricht Kriterleri. Bankactlar Dergisi, 52, 67-86.

Jesionowski, M. (1996). Economic Competitiveness of Selected European Countries, International Advances in Economic Research, 2(3), 295-299.

Kalibatas, D., Turskis Z. (2008). Multicriteria Evaluation of Inner Climate by Using MOORA Method. Information Technology and Control, 37(1), 79-83.

Karabulut, K., Ersungur, Ş.M., Polat, Ö. (2008). Avrupa Birliği Ülkeleri ve Türkiye’nin Ekonomik Performanslarının Karşılaştırılması: Veri Zarflama Analizi. Atatürk Üniversitesi, İktisadi ve İdari Bilimler Fakültesi Dergisi, 22 (1), 1-11.

Karaca, T. (2011). Proje Yönetiminde Çok Kriterli Karar Verme Teknikleri Kullanarak Kritik Yolun Bulunması. (Yayımlanmamış yüksek lisans tezi). Gazi Üniversitesi/ Fen Bilimleri Enstitüsü, Ankara.
Kracka, M., Brauers, W.K.M., Zavadskas, E.K. (2010). Ranking Heating Losses in a Building by Applying the Multimoora, Inzinerine Ekonomika- Engineering Economies, 21(4), 352-359.

Lai, Y. J., Liu, T. Y., Hwang, C. L. (1994). TOPSIS for MCDM, European Journal of Operational Research, 76, 486-500.

Mandal, U. K.ve Sarkar, B. (2012). Selection of Best Intelligent Manufacturing System Under Fuzzy MOORA Conflicting MCDM Environment. International Journal of Engineering Technology and Advanced Engineering, 2(9), 301-310.

Önay, O. (2014). MOORA. B.F. Ylldırım, E. Önder (Ed.), Çok Kriterli Karar Verme Yöntemleri içinde (s.247-257). Bursa: Dora Yaymcilik.

Önay, O., Çetin, E. (2012). Turistik Yerlerin Popülaritesinin Belirlenmesi: İstanbul Örneği. Yönetim: İstanbul Üniversitesi İ̧sletme İktisadı Enstitüsü Dergisi, 23(72), 90-109.

Özden Ü. H. (2011). TOPSIS Yöntemi İle Avrupa Birliğine Üye ve Aday Ülkelerin Ekonomik Göstergelere Göre Siralanması. Trakya Üniversitesi Sosyal Bilimler Dergisi, 13(2), 215-236.

Özden, Ü. H. (2012). AB’ye Üye Ülkelerin ve Türkiyennin Ekonomik Performanslarına Göre VIKOR Yöntemi ile Sıralanması. İstanbul Ticaret Üniversitesi Sosyal Bilimler Dergisi, 11(21), 455468.

Özer, M. (2010). Taşınmaz Değerlemesinde Kullantlan Finansal ve Sayısal Yöntemler: TOPSIS Ve Yeni Çoklu Kriter Modelleriyle Bir Uygulama, (Yayımlanmamış yüksek lisans tezi). Dokuz Eylül Üniversitesi/Sosyal Bilimler Enstitüsü, İzmir.

Šltés, T. (2012). Competitiveness Position of Slovak Republic - Various Measures Comparison, Innovative Issues and Approaches in Social Sciences, 5(3), 41-64. 
Tatoğlu, E. (2006). Avrupa Birliğinin Tarihsel Gelișimi (1951- 1995). (Yayımlanmamış yüksek lisans tezi). Ankara Üniversitesi. Türk İnkılap Tarihi Enstitüsü Atatürk İlkeleri ve İnkılap Tarihi Anabilim Dalı, Ankara.

Tekin, A. S. (2011). Etkinlik Hesaplama Yöntemi Olarak Veri Zarflama Analizi ve Avrupa Birliği Ülkeleri ve Türkiye’nin Göreli Finansal Etkinliklerinin Değerlendirilmesine İlişkin Bir Uygulama. (Yayımlanmamış yüksek lisans tezi). Yıldız Teknik Üniversitesi/ Sosyal Bilimler Enstitüsü, İstanbul.

Tepe, S., Görener, A. (2014). Analitik Hiyerarşi Süreci ve MOORA Yöntemlerinin Personel Seçiminde Uygulanması. İstanbul Ticaret Üniversitesi Fen Bilimleri Dergisi, 13(25), 1-14

Tong L. L., Wang C. H. Chen H. C. (2005). Optimization of Multiple Responses Using Principal Component Analysis and Technique for Order Preference by Similarity to Ideal Solution. International Journal of Advenced Manufacturing Technology, 27, 407-414.

Triantaphyllou, E. (2000). Multi-Criteria Decision Making Methods: A Comparative Study, , Applied Optimization, Vol. 44, USA: Kluwer Academic Publishers.
Urfalıŏlu, F., Genç, T., (2013). Çok Kriterli Karar Verme Teknikleri ile Türkiye'nin Ekonomik Performansının Avrupa Birliği Üye Ülkeleri ile Karşılaştırılması. Marmara Üniversitesi İ.I..B. Dergisi, 35 (2), 329-360.

Ünal, G. (2008). Lojistikte Hizmet Sağlayıcı Seçiminde AHP Ve TOPSIS Yöntemlerinin Uygulanması. (Yayımlanmamış yüksek lisans tezi). Kocaeli Üniversitesi/Fen Bilimler Enstitüsü, Kocaeli.

Wang Y. M., Elhag T. M. S. (2006). Fuzzy TOPSIS Method Based on Alpha Level Setswith An Application to Bridge Risk Assessment. Expert Systems with Applications 31, 309-319.

Yurdakul M., İç Y. T. (2003). Türk Otomotiv Firmalarının Performans Ölçümü ve Analizine Yönelik TOPSIS Yöntemini Kullanan Bir Örnek Çalışma. Gazi Üniversitesi Mühendislik-Mimarlık Fakültesi Dergisi, 18, 1-18.

http://epp.eurostat.ec.europa.eu/portal/page/portal/ eurostat/home/

http://evds.tcmb.gov.tr/cbt.html

http://www.mfa.gov.tr/luksemburg-ekonomisi.tr.mfa

http://www.mfa.gov.tr/yunanistan-ekonomisi.tr.mfa 